\title{
Tropical Pacific Influence on the Source and Transport of Marine Aerosols to West Antarctica*
}

\author{
Alison S. CRiscitiello, ${ }^{+}$SARAH B. DAS, ${ }^{\#}$ Kristopher B. KARnAuskas, ${ }^{\#}$ \\ MatThew J. Evans, ${ }^{@}$ KAREn E. Frey, ${ }^{\&}$ IAN Joughin, ${ }^{* *}$ ERIC J. Steig, ${ }^{++}$ \\ JOSEPH R. MCCONNELL, \#\# AND BROOKE MEDLEY ${ }^{@ @ ~}$ \\ ${ }^{+}$Massachusetts Institute of Technology/WHOI Joint Program in Oceanography/Applied Ocean Science and Engineering, \\ and Department of Geology and Geophysics, Woods Hole Oceanographic Institution, Woods Hole, Massachusetts \\ " Department of Geology and Geophysics, Woods Hole Oceanographic Institution, Woods Hole, Massachusetts \\ ${ }^{\circledR}$ Department of Chemistry, Wheaton College, Norton, Massachusetts \\ \& Graduate School of Geography, Clark University, Worcester, Massachusetts \\ ** Department of Earth and Space Sciences, and Applied Physics Laboratory, University of Washington, Seattle, Washington \\ ${ }^{++}$Quaternary Research Center, University of Washington, Seattle, Washington \\ \#\# Desert Research Institute, Reno, Nevada \\ $@$ Department of Earth and Space Sciences, University of Washington, Seattle, Washington
}

(Manuscript received 13 March 2013, in final form 5 October 2013)

\begin{abstract}
The climate of West Antarctica is strongly influenced by remote forcing from the tropical Pacific. For example, recent surface warming over West Antarctica reflects atmospheric circulation changes over the Amundsen Sea, driven by an atmospheric Rossby wave response to tropical sea surface temperature (SST) anomalies. Here, it is demonstrated that tropical Pacific SST anomalies also influence the source and transport of marine-derived aerosols to the West Antarctic Ice Sheet. Using records from four firn cores collected along the Amundsen coast of West Antarctica, the relationship between sea ice-modulated chemical species and large-scale atmospheric variability in the tropical Pacific from 1979 to 2010 is investigated. Significant correlations are found between marine biogenic aerosols and sea salts, and SST and sea level pressure in the tropical Pacific. In particular, La Niña-like conditions generate an atmospheric Rossby wave response that influences atmospheric circulation over Pine Island Bay. Seasonal regression of atmospheric fields on methanesulfonic acid (MSA) reveals a reduction in onshore wind velocities in summer at Pine Island Bay, consistent with enhanced katabatic flow, polynya opening, and coastal dimethyl sulfide production. Seasonal regression of atmospheric fields on chloride $\left(\mathrm{Cl}^{-}\right)$reveals an intensification in onshore wind velocities in winter, consistent with sea salt transport from offshore source regions. Both the source and transport of marine aerosols to West Antarctica are found to be modulated by similar atmospheric dynamics in response to remote forcing. Finally, the regional icecore array suggests that there is both a temporally and a spatially varying response to remote tropical forcing.
\end{abstract}

\section{Introduction}

Marine aerosols (biogenic and sea salts) play an important role in many atmospheric processes (Fitzgerald 1991) and directly affect Antarctic climate. Marine biogenic

\footnotetext{
* Supplemental information related to this paper is available at the Journals Online website: http://dx.doi.org/10.1175/JCLI-D-1300148.s1.

Corresponding author address: A. S. Criscitiello, Woods Hole Oceanographic Institution, Geology and Geophysics, 266 Woods Hole Road MS 23, Woods Hole, MA 02543.

E-mail: glacierz@gmail.com
}

aerosols transported to Antarctica originate from oceanic areas of high primary productivity, which emit dimethyl sulfide (DMS) during and after sea ice breakup (Dacey and Wakeham 1986). As such, atmospheric DMS concentrations peak in the austral summer when oceanic primary productivity is high (Ayers et al. 1997). DMS is subsequently oxidized in the atmosphere to methanesulfonic acid (MSA; Ravishankara et al. 1997). Maximum MSA concentrations found on the adjacent ice sheet occur in snowfall deposited during the austral summer (Criscitiello et al. 2013), as expected since the lifetimes of DMS and MSA in the polar atmosphere are short ( $<7$ days; Hezel et al. 2011). Both DMS and MSA interact with incoming solar radiation, affecting cloud 
albedo and regional climate (Charlson et al. 1987). These biogenic marine aerosols significantly increase cloud droplet concentrations over phytoplankton blooms, resulting in a decrease in shortwave radiation flux at the top of the atmosphere and an enhancement of cloud condensation nuclei production (Meskhidze and Nenes 2006). Sulfur species such as DMS are also a large contributor to the acidity of the atmosphere (Legrand 1997).

In contrast to marine biogenic species, the seasonality of sea-salt aerosols varies regionally, as there are several processes associated with the production of sea-salt aerosols at high latitudes. Some studies have shown that processes associated with sea ice formation (e.g., frost flower formation, brine production, and blowing snow released from sea ice surfaces), primarily occurring from late summer through winter, are the dominant source of sea-salt aerosols for Antarctica (Rankin et al. 2002; Wolff et al. 2003; Kaleschke et al. 2004; Wolff et al. 2006; Fischer et al. 2007; Yang et al. 2008; Roscoe et al. 2011; Criscitiello et al. 2013). Other studies have instead suggested that open water in the marginal sea ice zone, particularly during stormy seasons, promotes increased production, transport, and deposition of sea-salt aerosols (Petit et al. 1999; Kinnard et al. 2006; Abram et al. 2011). Whether enhanced sea-salt aerosol fluxes reflect increased open water or increased sea ice cover in a particular region, sea-salt aerosols ubiquitously affect climate by scattering and absorbing radiation and influencing the albedo of marine boundary layer clouds (Fitzgerald 1991).

The strong relationship between sea surface conditions and marine aerosols also means that in coastal regions of Antarctica, where annual precipitation rates are high, high-resolution ice-core records allow for reconstruction of past ocean surface and sea ice conditions (e.g., Thomas et al. 2009). MSA and sea-salt aerosols $\left(\mathrm{Na}, \mathrm{Cl}, \mathrm{Mg}, \mathrm{K}, \mathrm{Ca}\right.$, and $\mathrm{SO}_{4}$ ) have been used as qualitative proxies for regional sea ice extent (SIE) around Antarctica [see Abram et al. (2013) for a review, and references therein]. In a previous study we focused on the spatial relationships between ice-sheet chemistry adjacent to Pine Island Bay, West Antarctica, and satellitederived sea ice concentration (SIC) in the Amundsen Sea (including polynya activity), to further our understanding of marine-aerosol source variability in this region (Criscitiello et al. 2013). Winds also affect the transport of marine aerosols to the ice sheet and thus need to be considered in the interpretation of ice-core records.

Because winds are ultimately forced by remote largescale atmospheric dynamics, the transport of marine aerosols may also be affected by regional- to globalscale phenomena. The tropical Pacific strongly influences atmospheric circulation at high northern and southern latitudes (Trenberth et al. 1998). Tropical Pacific sea surface temperature (SST) variability influences the upper troposphere, enhancing convection and upper tropospheric divergence near the equator (Trenberth et al. 1998). The resulting wave train of alternating high and low pressure emanates both north and south. In the Southern Hemisphere (SH), there is a strong teleconnection between the tropical Pacific and West Antarctica as a result of this increased convection in the central tropical Pacific during El Niño and La Niña conditions, which gives rise to a pattern of stationary Rossby waves that propagate to the extratropical SH (e.g., Hoskins and Karoly 1981; Karoly 1989; Jin and Hoskins 1995; Trenberth et al. 1998; Turner 2004; Lachlan-Cope and Connolley 2006). The widespread recent warming in continental West Antarctica has been linked to SST changes in the tropical Pacific (Ding et al. 2011; Schneider et al. 2012; Ding et al. 2012; Steig et al. 2013).

Observational and modeling studies have also documented the strong influence of the leading patterns of tropical and SH large-scale climate variability [El NiñoSouthern Oscillation (ENSO) and the southern annular mode (SAM)] on polar records including melting events in West Antarctica (e.g., Trusel et al. 2012) and marine aerosols and SIC around Antarctica (Yuan and Martinson 2001; Hall and Visbeck 2002; Kwok and Comiso 2002; Lefebvre et al. 2004; Liu et al. 2004; Stammerjohn et al. 2008; Yuan and Li 2008; Simpkins et al. 2012). One recent study identified a highly significant ENSO signature (during 1889-2009) in a sea-salt record from Law Dome, East Antarctica (Vance et al. 2013). Work is ongoing, but many studies suggest that the tropicalextratropical connection between ENSO and Antarctica is highly variable, depending on the exact pattern and zonal distribution of tropical SST anomalies and zonal winds in the South Pacific (Turner 2004; Fogt and Bromwich 2006; Lachlan-Cope and Connolley 2006; L'Heureux and Thompson 2006; Fogt et al. 2011). Tropical Pacific variability not directly related to ENSO also influences high-latitude circulation (LachlanCope and Connolley 2006; Ashok et al. 2007; Schneider and Steig 2008; Ding et al. 2011). In particular, SST anomalies under areas of strong tropical convection have a significant influence on atmospheric circulation in the Amundsen Sea region, through the generation of a Rossby wave train (Lachlan-Cope and Connolley 2006). As our understanding of low- to high-latitude Pacific Ocean teleconnections evolves, investigators are beginning to examine scarce but potentially proxy-rich Antarctic data for tropical Pacific signatures (e.g., Okumura et al. 2012; Vance et al. 2013; Steig et al. 2013). Several studies of Pacific extratropical teleconnections to high 


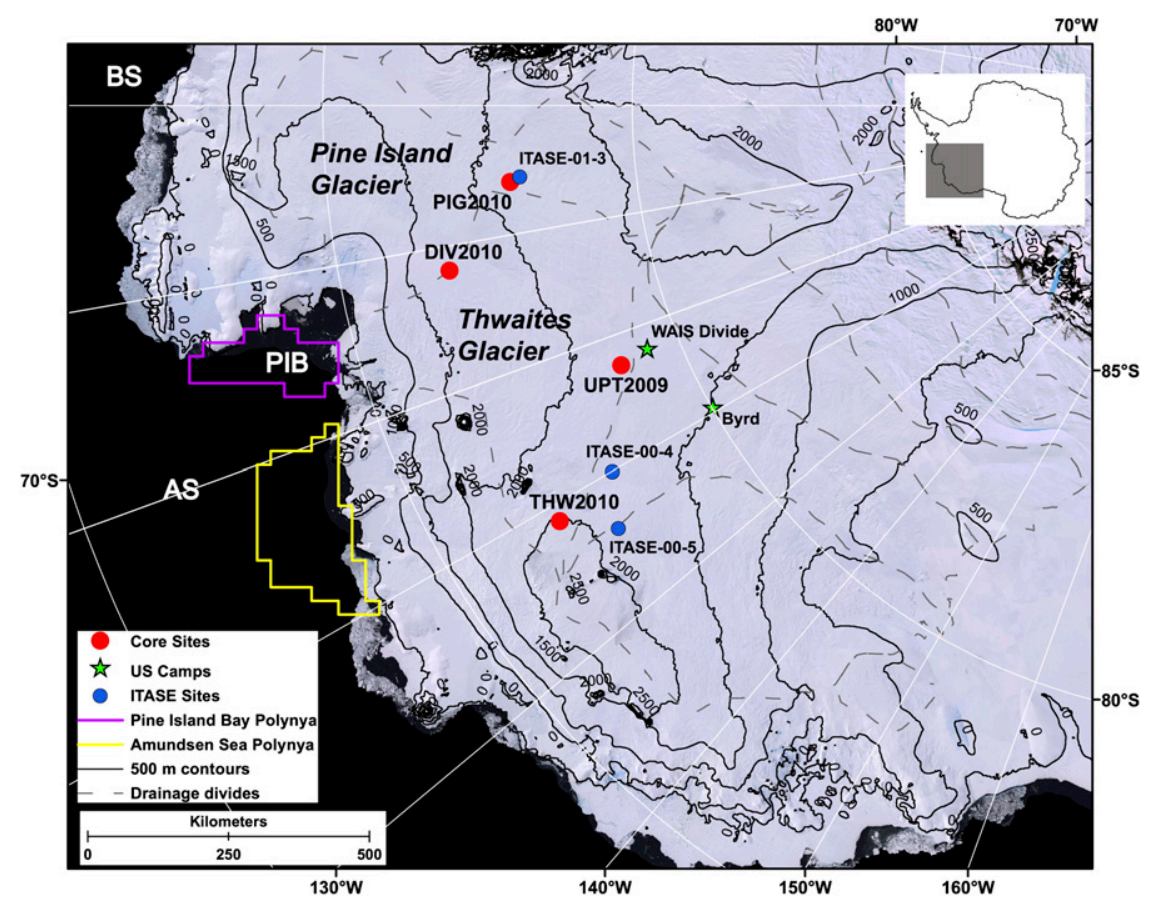

FIG. 1. Regional setting of West Antarctica. Gray box in inset shows map location. Background Moderate Resolution Imaging Spectroradiometer (MODIS) mosaic of Antarctica is shown with 500-m contour intervals (black solid lines) and drainage divides (gray dashed lines). The DIV2010, PIG2010, THW2010, and UPT2009 drill sites are shown (red circles), as are Byrd and WAIS Divide (green stars) and relevant ITASE cores (blue circles). Bellingshausen Sea is denoted by BS. The PIB polynya mask is shown in purple, and the AS polynya mask is shown in yellow (derived from SMMR- and SSM/I-based SIC).

southern latitudes have focused on West Antarctica, where the extratropical signal is especially strong and has been linked to variability in SST, precipitation, sea level pressure (SLP), SIE, and sea ice thickness (e.g., Cullather et al. 1996; Kwok and Comiso 2002; Turner 2004; Yuan and Li 2008; Ding et al. 2011).

In this study, we provide a first assessment of the influence of the tropical Pacific on the source and transport of marine aerosols to the West Antarctic Ice Sheet (WAIS). We focus on the effects of large-scale atmospheric circulation on four new marine-aerosol ice-sheet records from the Amundsen Coast of West Antarctica. We carry out least squares linear temporal regression analyses of global reanalysis fields on seasonally stratified anomalies of firn-core chemical composition to investigate the large-scale atmospheric processes that influence the transport of marine aerosols, and thus in turn influence ice-sheet chemistry, in the region. This both aids in our interpretation of ice-core marineaerosol records in West Antarctica and provides additional evidence of the teleconnection between the tropical Pacific and the Amundsen Sea (previously shown using SST, SLP, and SIC) with independent icesheet variables.

\section{Methods and datasets}

\section{a. Site description and core collection}

The Amundsen Sea is characterized by a relatively narrow continental shelf, a large amount of perennial sea ice, and several coastal polynyas located adjacent to large ice shelves (Arrigo and van Dijken 2003). Surface waters associated with these polynyas have enhanced rates of primary and secondary production (Arrigo and van Dijken 2003; Arrigo et al. 2012) and some of the highest abundances of phytoplankton in the world (Smith and Gordon 1997). The Amundsen Sea (AS) and Pine Island Bay (PIB) polynyas (Fig. 1) are latent heat polynyas, meaning that they are influenced largely by local katabatic winds (Marshall and Turner 1997) and the associated transport of sea ice away from the coast (Pease 1987). Pine Island, Thwaites, and Smith Glaciers are the principal drainage systems of the Amundsen Sea sector of WAIS (Shepherd et al. 2002), with approximately $25 \%$ of the area of WAIS draining into the Amundsen Sea embayment (Rignot et al. 2002). The highest rates of mass loss and glacier acceleration in Antarctica outside of the Antarctic Peninsula have occurred along the Amundsen-Bellingshausen Sea in the 
TABLE 1. List of four West Antarctic firn cores used in this study.

\begin{tabular}{|c|c|c|c|c|c|c|c|c|}
\hline Site & Lat & Lon & Elev (m) & $\begin{array}{l}\text { Distance from } \\
\text { coast }(\mathrm{km})\end{array}$ & Period & 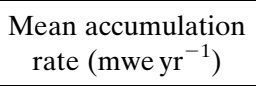 & $\begin{array}{c}\text { MSA range } \\
(\mathrm{ppb})\end{array}$ & $\begin{array}{c}\mathrm{Cl}^{-} \text {range } \\
(\mathrm{ppb})\end{array}$ \\
\hline DIV2010 & $76.8^{\circ} \mathrm{S}$ & $101.7^{\circ} \mathrm{W}$ & 1329 & 180 & 1979-2010 & 0.408 & $1.1-44.8$ & $14.2-212.6$ \\
\hline PIG2010 & $78.0^{\circ} \mathrm{S}$ & $96.0^{\circ} \mathrm{W}$ & 1593 & 350 & 1992-2010 & 0.424 & $2.6-31.7$ & $19.0-282.7$ \\
\hline THW2010 & $77.0^{\circ} \mathrm{S}$ & $121.2^{\circ} \mathrm{W}$ & 2020 & 340 & 1979-2010 & 0.281 & $2.0-31.3$ & $12.2-244.6$ \\
\hline UPT2009 & $79.0^{\circ} \mathrm{S}$ & $112.6^{\circ} \mathrm{W}$ & 1765 & 500 & 1992-2009 & 0.290 & $0.8-22.6$ & $19.3-503.3$ \\
\hline
\end{tabular}

Pine Island and Thwaites Glacier regions, as a result of increases in ocean heat transport beneath its ice shelves (Jenkins et al. 2010; Jacobs et al. 2011; Steig et al. 2012). Continental West Antarctica has also experienced substantial warming in the past 50 years (Steig et al. 2009; Orsi et al. 2012; Bromwich et al. 2013). Trends in SIC provide independent evidence of the observed warming over West Antarctica; the decrease in sea ice area in the Amundsen and Bellingshausen Seas has been shown to be congruent with at least $50 \%$ of the inland warming of West Antarctica (Ding et al. 2011; Schneider et al. 2012). Owing to these recent changes, there is a strong need to develop longer histories of environmental variability in this region, as well as a better understanding of the largescale, remote drivers of such variability.

In this study, we used new firn cores from Pine Island Glacier (PIG2010), Thwaites Glacier (THW2010 and UPT2009), and the drainage divide between Pine Island and Thwaites Glaciers (DIV2010) to reconstruct marineaerosol histories (Fig. 1). These core sites range in elevation from 1329 to $2020 \mathrm{~m}$, and range from 180 to $500 \mathrm{~km}$ in distance from the coast (Table 1). Accumulation rates at the sites are relatively high, ranging from 0.28 to 0.42 mwe yr $^{-1}$ [meter water equivalent (mwe); Table 1]. Annual accumulation variability is high at all sites, and shows no significant recent trend (Medley et al. 2013). Ice velocities at the core locations are low $\left(\sim 10-20 \mathrm{~m} \mathrm{yr}^{-1}\right.$; Joughin et al. 2003). We drilled the UPT2009 firn core in December 2010 using a 3-in.-diameter Polar Ice Coring Office (PICO) hand auger, and the DIV2010, PIG2010, and THW2010 firn cores in December 2011 using a Badger-Eclipse drill. For the purposes of this study, we focus on ice-core records from 1979 to 2010 (where available) in order to provide the best overlap with the European Centre for Medium-Range Weather Forecasts (ECMWF) Interim Re-Analysis (ERA-Interim) dataset.

\section{b. Glaciochemical records}

Data for the DIV2010, PIG2010, and THW2010 cores include MSA, total soluble plus insoluble sulfur $\left(\mathrm{S}_{\text {total }}\right)$, sodium (Na), chloride $\left(\mathrm{Cl}^{-}\right)$, calcium $(\mathrm{Ca})$, and magnesium $(\mathrm{Mg})$. Data for the UPT2009 core are limited to MSA and $\mathrm{Cl}^{-}$. We performed MSA and $\mathrm{Cl}^{-}$analyses using suppressed ion chromatography (Curran and Palmer 2001; Morganti et al. 2007). The detection limits of this procedure are 0.4 and $10 \mathrm{ppb}$ for MSA and $\mathrm{Cl}^{-}$, respectively, with analytical precision of $<5 \%$. We performed analyses of $\mathrm{S}_{\text {total }}, \mathrm{Na}, \mathrm{Ca}$, and $\mathrm{Mg}$ using mass spectrometry (detection limits $\sim 500$ ppq for elements in this study; McConnell et al. 2001). To avoid timing uncertainty generating errors in correlation with large-scale reanalysis fields, we applied a three-point running mean to all monthly glaciochemical time series. Normalized time series presented in Fig. 2 are standard score normalizations $[Z=(X-\mu) / \sigma]$. Composite annual cycles of MSA and $\mathrm{Cl}^{-}$presented in Fig. 3 are monthly climatology means of all months available for each record (1979-2010 for DIV2010 and THW2010, 1992-2010 for PIG2010, and 1992-2009 for UPT2009). Note that using the same time interval for all records (1992-2009) reveals similar results.

To aid in dating, oxygen isotopes in all firn cores were measured at a minimum of $5-\mathrm{cm}$ resolution following methods of Maselli et al. (2013). We established an age-depth relationship and determined accumulation rates following standard methods [see the supplemental material and Criscitiello et al. (2013) for detailed methods]. The high accumulation rates at the core sites (Table 1) allow for seasonal resolution of the core records $\left(\sim 14\right.$ samples $\mathrm{yr}^{-1}$ even at the lower accumulation sites on Thwaites Glacier), and limit postdepositional loss of MSA (Weller et al. 2004). To allow investigation of chemical species alongside reanalysis records, we produced monthly-resolution records (Fig. 2). We calculated these monthly results by linearly interpolating between measured concentrations (which are not evenly spaced in time as a result of irregular core breaks, variations in accumulation rate, etc.), and then averaging these interpolated time series. Finally, we created seasonal time series of the glaciochemical records. Because MSA deposition occurs almost entirely in summer, we created a time series of summertime MSA deposition. The summer season was defined as November-March to coincide with the peak MSA deposition month \pm 2 months (Fig. 3). Since there is a broad $\mathrm{Cl}^{-}$peak in winter but it is deposited year-round, we created summer (November-March) and winter (June-October) time series, with the winter season centered on the peak $\mathrm{Cl}^{-}$deposition month (Fig. 3). 


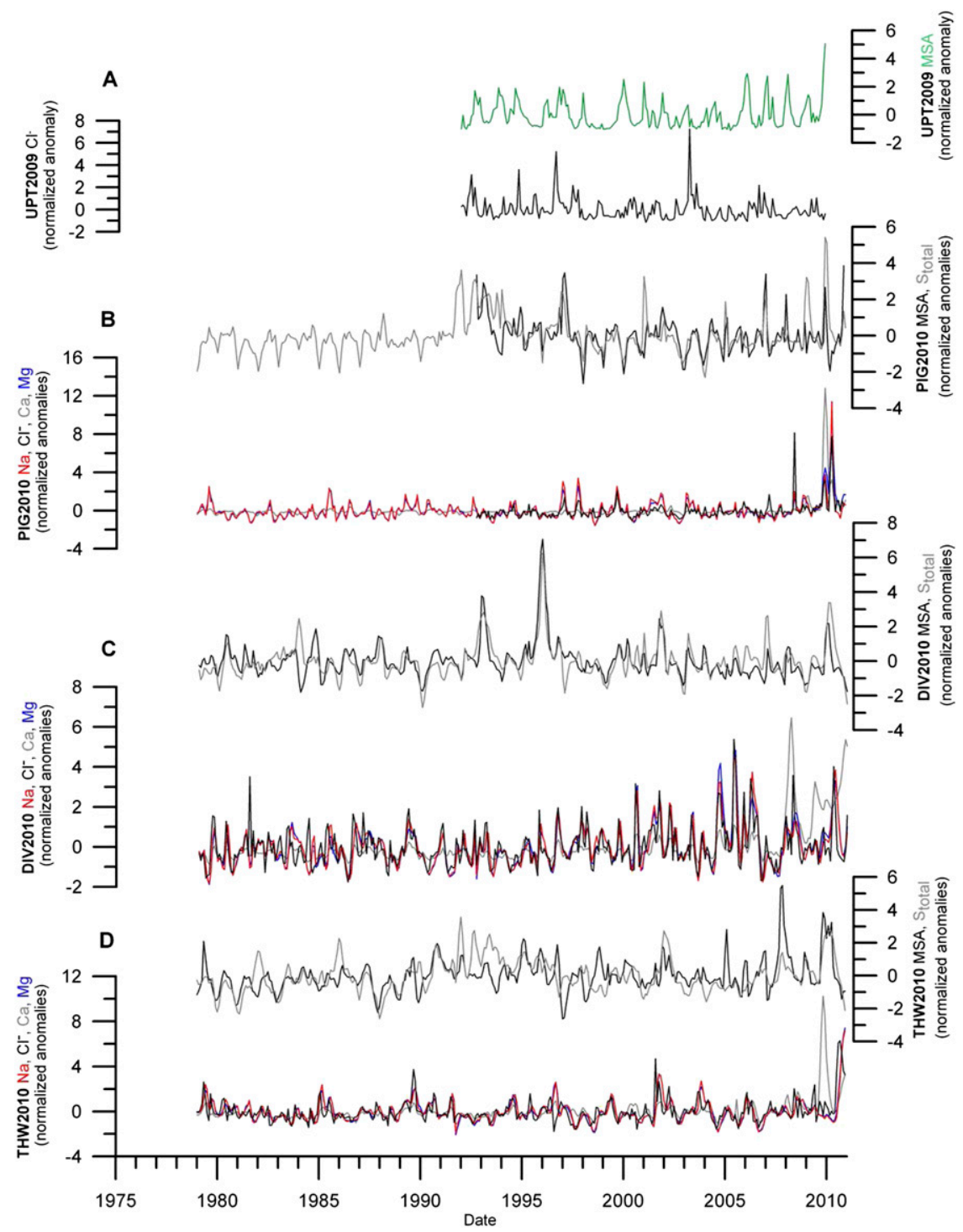

FIG. 2. Normalized time series of (a) UPT2009 MSA (green) and $\mathrm{Cl}^{-}$(black) anomalies (only MSA and $\mathrm{Cl}^{-}$data exist for UPT2009); normalized time series of $\mathrm{Na}$ (red), $\mathrm{Cl}^{-}$(black), $\mathrm{Ca}$ (gray), Mg (blue), MSA (black), and $\mathrm{S}_{\text {total }}$ (gray) anomalies for (b) PIG2010, (c) DIV2010, and (d) THW2010. Sea-salt species and marine biogenic species at each site covary.

\section{c. Observational climate datasets}

We utilized ERA-Interim products (Dee et al. 2011) to provide global monthly SLP, 500-hPa geopotential height (GH), SST, and zonal and meridional wind velocities over the study period. We analyzed these variables to investigate the spatial relationships between chemical signals recorded in the DIV2010, PIG2010, THW2010, and UPT2009 cores and climate fields. To improve results relative to the earlier 40-yr ECMWF Re-Analysis (ERA-40) data, we used ERA-Interim reanalysis data (Berrisford et al. 2009; Dee et al. 2011) because it has a higher horizontal $\left(0.75^{\circ} \times 0.75^{\circ}\right)$ and vertical resolution and improved model physics and characterization of the hydrological cycle. Recent assessments for the Amundsen Sea region of Antarctica indicate that ERA-Interim is the most reliable reanalysis product for this region of Antarctica that is currently available (Bracegirdle 2013). ERA-40 is known to have limitations in the Antarctic Peninsula region because it insufficiently resolves the mountainous terrain (Miles et al. 2008). To reduce subseasonal noise unrelated to tropical forcing, we applied a three-point running mean to all the monthly data as well (similar to the glaciochemical records). 


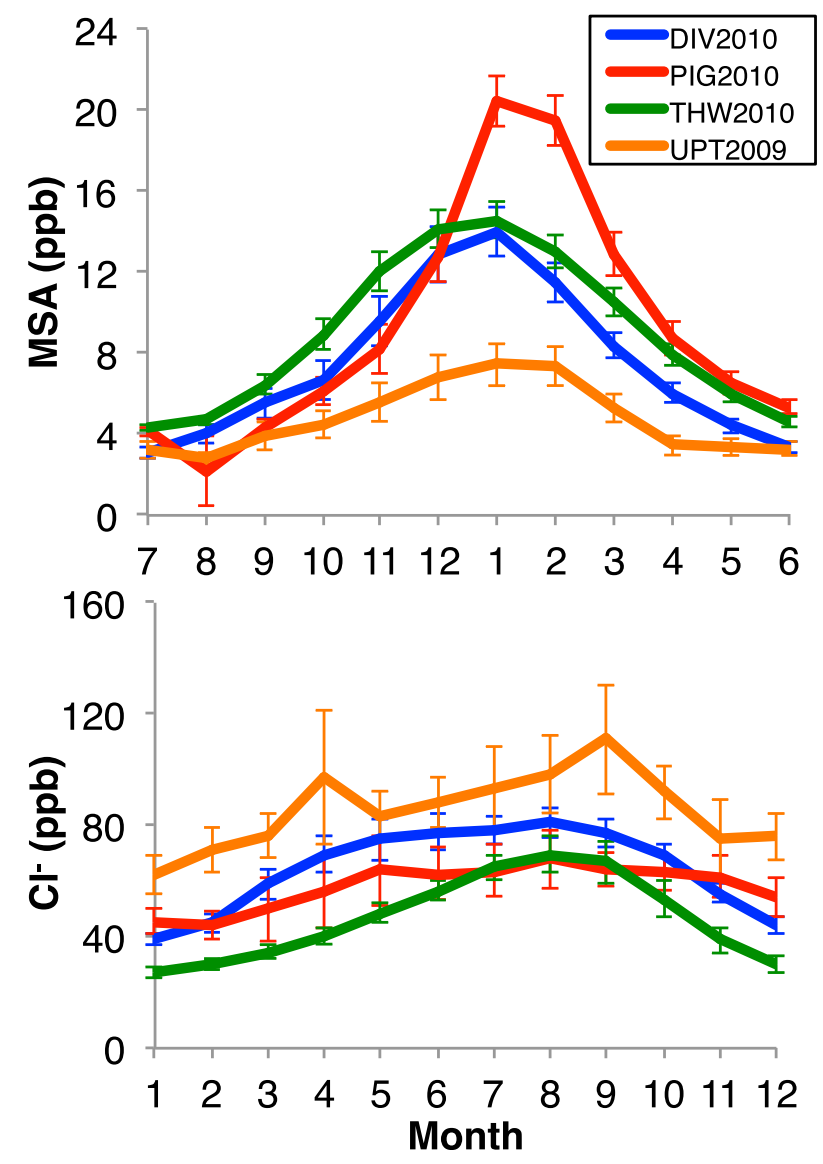

FIG. 3. Seasonal cycle of MSA and $\mathrm{Cl}^{-}$at DIV2010 (blue), PIG2010 (red), THW2010 (green), and UPT2009 (orange). Error bars indicate \pm 2 standard errors. Annual MSA maxima occur in austral summer (DJF), and annual $\mathrm{Cl}^{-}$maxima occur in austral winter (JJA). Note that MSA and $\mathrm{Cl}^{-}$are shown with different $x$ axes.

Seasonal reanalysis fields were defined the same as for the glaciochemical records (previously described in section $2 \mathrm{~b}$ ). Our results are presented as seasonal anomalies (i.e., as deviations from the long-term mean climatology). We conducted least squares linear temporal regression analyses of atmospheric fields on the seasonal anomalies of the firn-core glaciochemical records (please see the supplemental material for monthly regression figures). Only linear regression maps for positive MSA and $\mathrm{Cl}^{-}$deposition are presented, although we note that anomaly patterns of opposite sign for negative deposition anomalies inherently exist. Statistical significance for the seasonal regressions was determined using the two-tailed Student's $t$ test $(p<0.05)$. In addition, we performed lead/lag tests $(0, \pm 1$, and \pm 2 months) between glaciochemical time series and reanalysis data. These did not reveal a systematic lead/lag relationship; therefore, only 0-lag results are presented. Finally, we created stacked records of MSA and $\mathrm{Cl}^{-}$(by averaging the monthly MSA and $\mathrm{Cl}^{-}$data from the four sites), which did not yield correlations or regressions (strength or spatial patterns) distinct from individual site results and are therefore not presented.

\section{d. Polynya total open water area and regional SIE}

We created polynya and SIE time series to examine the link between remote atmospheric forcing of regional winds and polynya and sea ice variability specifically relevant to this study. To examine polynya variability directly linked with local DMS production and marine biogenic aerosol deposition on the ice sheet, we derived an open water time series for the sea surface within the Pine Island Bay and Amundsen Sea polynyas (Fig. 1), regions that previously have been shown to correlate significantly with MSA at DIV2010 (Criscitiello et al. 2013). Polynya masks (Fig. 1) were defined using methods outlined in Criscitiello et al. (2013), but here we utilized Scanning Multichannel Microwave Radiometer (SMMR) and Special Sensor Microwave Imager (SSM/I) passive microwave data of SIC from 1979 to 2010 rather than Advanced Microwave Scanning Radiometer for Earth Observing System (AMSR-E) data used previously (as AMSR-E data are only available for 2002-present). Using these polynya masks, we extracted daily open water areas (1979-2010) by summing the pixels $(25 \mathrm{~km} \times 25 \mathrm{~km})$ that had $<15 \%$ SIC (our defined threshold value for open water). Next, we summed the daily open water areas of the Pine Island Bay and Amundsen Sea polynyas, and then averaged these daily values to generate a monthly time series of polynya total open water area (TOWA) to produce a time series of the TOWA anomalies (please see the supplemental material for monthly regression figures of atmospheric fields on TOWA). Finally, we smoothed the monthly TOWA anomaly time series with a 3-month running mean, and created a summer (November-March) time series from these monthly data, as we did with the reanalysis data and MSA time series. We present regressions of reanalysis fields on summer TOWA, as summer is the deposition season for MSA.

The primary source of sea salts to this region is a much larger region around the leading seasonal ice edge as well as near $70^{\circ} \mathrm{S}$ between approximately $97^{\circ}$ and $107^{\circ} \mathrm{W}$, largely outside the polynyas described above (Criscitiello et al. 2013). Thus, to examine the relationship between remote atmospheric forcing of regional winds and SIE over this larger offshore region, we created a separate SIE time series. This time series also utilizes SMMR- and SSM/I-based SIC, but in this case we created a monthly time series (1979-2010) of SIE between $80^{\circ}$ and $140^{\circ} \mathrm{W}$, and $60^{\circ}$ and $71^{\circ} \mathrm{S}$, where SIE is defined as the total area within this defined region with SIC $>15 \%$ 
(please see the supplemental material for monthly regression figures of atmospheric fields on SIE). We then created summer and wintertime series from this monthly data, as we did with the reanalysis data and $\mathrm{Cl}^{-}$time series. We present both summer and winter regressions of reanalysis fields on SIE, as sea salts have a broad peak encompassing winter but with nontrivial deposition rates year-round (Fig. 3).

\section{Results}

\section{a. Glaciochemical records}

Our measured MSA and $\mathrm{Cl}^{-}$concentrations in the DIV2010, PIG2010, THW2010, and UPT2009 cores (Table 1) are comparable to concentrations found in other recent Antarctic cores (e.g., Abram et al. 2011). The highest measured MSA concentrations are from the two lower elevation sites: the DIV2010 core (44.8 ppb, the site closest to Pine Island Bay) and the PIG2010 core $(31.7 \mathrm{ppb})$, while the lowest concentrations are from the UPT2009 core $(22.6 \mathrm{ppb}$, the site farthest from Pine Island Bay; Table 1). The opposite is found in the $\mathrm{Cl}^{-}$ records, where the highest measured $\mathrm{Cl}^{-}$concentrations are from the UPT2009 core (503.3 ppb), and the lowest concentrations are from the DIV2010 core $(212.6 \mathrm{ppb}$; Table 1).

MSA has a strong seasonal cycle at all sites (Fig. 3), being deposited almost entirely in summer [DecemberFebruary (DJF)] with annual minima during austral winter [June-August (JJA)], while $\mathrm{Cl}^{-}$has a broad peak in winter but with substantial deposition year-round at all sites (Fig. 3). These results are consistent with a previous study at the DIV2010 site that found the MSA maxima during summer months were derived from marine biological productivity during spring and summer, while $\mathrm{Cl}^{-}$maxima during winter months originated primarily from winter sea ice formation (Criscitiello et al. 2013). While maximum measured MSA concentrations are highest in the DIV2010 record and lowest in the UPT2009 record, the climatology reveals that PIG2010 has the highest composite summer MSA concentrations, and UPT2009 has the lowest composite summer MSA concentrations (Fig. 3). Similarly, while the maximum measured $\mathrm{Cl}^{-}$concentrations are highest in the UPT2009 record and lowest in the DIV2010 record (Table 1), the climatology reveals that UPT2009 also has the highest composite winter $\mathrm{Cl}^{-}$concentrations, but THW2010 and PIG2010 have the lowest composite winter $\mathrm{Cl}^{-}$concentrations (Fig. 3).

There are significant correlations between normalized sea-salt species anomalies $\left(\mathrm{Na}, \mathrm{Cl}^{-}, \mathrm{Ca}\right.$, and $\left.\mathrm{Mg}\right)$ at DIV2010, PIG2010, and THW2010 (Table 2), as has
TABLE 2. Pearson's $r$ correlation coefficients of monthly (unsmoothed) marine-aerosol anomalies (all significant at $p<$ 0.05 except PIG2010 Ca and $\mathrm{Cl}^{-}$, italicized).

\begin{tabular}{llccccc}
\hline \hline \multirow{5}{*}{ DIV2010 } & & $\mathrm{Na}$ & $\mathrm{Cl}^{-}$ & $\mathrm{Ca}$ & $\mathrm{Mg}$ & $\mathrm{S}_{\text {total }}$ \\
& $\mathrm{Na}$ & - & - & - & - & - \\
& $\mathrm{Cl}^{-}$ & 0.75 & - & - & - & - \\
& $\mathrm{Ca}$ & 0.39 & 0.31 & - & - & - \\
& $\mathrm{Mg}$ & 0.97 & 0.75 & 0.43 & - & - \\
PIG2010 & $\mathrm{MSA}$ & - & - & - & - & 0.71 \\
& $\mathrm{Na}$ & - & - & - & - & - \\
& $\mathrm{Cl}^{-}$ & 0.77 & - & - & - & - \\
& $\mathrm{Ca}$ & 0.44 & 0.42 & - & - & - \\
& $\mathrm{Mg}$ & 0.95 & 0.77 & 0.57 & - & - \\
& $\mathrm{MSA}$ & - & - & - & - & 0.55 \\
THW2010 & $\mathrm{Na}$ & - & - & - & - & - \\
& $\mathrm{Cl}$ & 0.60 & - & - & - & - \\
& $\mathrm{Ca}$ & 0.35 & 0.30 & - & - & - \\
& $\mathrm{Mg}$ & 0.99 & 0.63 & 0.36 & - & - \\
& $\mathrm{MSA}$ & - & - & - & - & 0.49 \\
\hline
\end{tabular}

been found at many other Antarctic sites (e.g., Artaxo et al. 1992; Abram et al. 2011). Correlations between sea-salt species are generally weakest (although still significant at $p<0.05$ ) at THW2010 (Table 2). Correlations between $\mathrm{Na}, \mathrm{Cl}^{-}$, and $\mathrm{Mg}$ at each site are stronger $(r>0.60, p<0.05)$ than correlations at each site between any of these sea-salt species and $\mathrm{Ca}(r>$ $0.30, p<0.05$; Table 2), likely resulting from the large aerosol size of $\mathrm{Ca}$, which results in a dilution effect at high accumulation rate sites (Herron 1982; Kreutz and Mayewski 1999). Owing to the strong correlation between sea-salt species, we have chosen $\mathrm{Cl}^{-}$as the representative sea-salt ion in the results presented below. Similarly, owing to the correlation $(r>0.49, p<0.05)$ between MSA and $\mathrm{S}_{\text {total }}$ at all sites (Table 2), we have chosen MSA as the representative biogenic species. This is further justified by the vast body of work focused on the sulfur cycle in the Antarctic and the various pathways and covariability among $\mathrm{S}_{\text {total }}$, DMS, and MSA (e.g., Cunningham and Zoller 1981; Pszenny et al. 1989). As with sea-salt species, correlations between marine biogenic species are weakest (although still significant at $p<0.05$ ) at THW2010 (Table 2).

\section{b. Global atmospheric anomalies}

At PIG2010, regressions of SLP and 500-hPa GH (Fig. 4) on summer MSA and winter $\mathrm{Cl}^{-}$reveal a low pressure anomaly over the western Antarctic Peninsula, which alternates with a high pressure anomaly in the central South Pacific and a low pressure anomaly in the western tropical Pacific (see also Fig. S2 in the supplemental material). These same patterns exist for DIV2010 (Fig. 5), although they are not statistically significant at $p<0.05$. The THW2010 summer regressions of SLP and 


\section{A Summer MSA \& SLP B Summer Cl \& SLP C Winter Cl \& SLP}
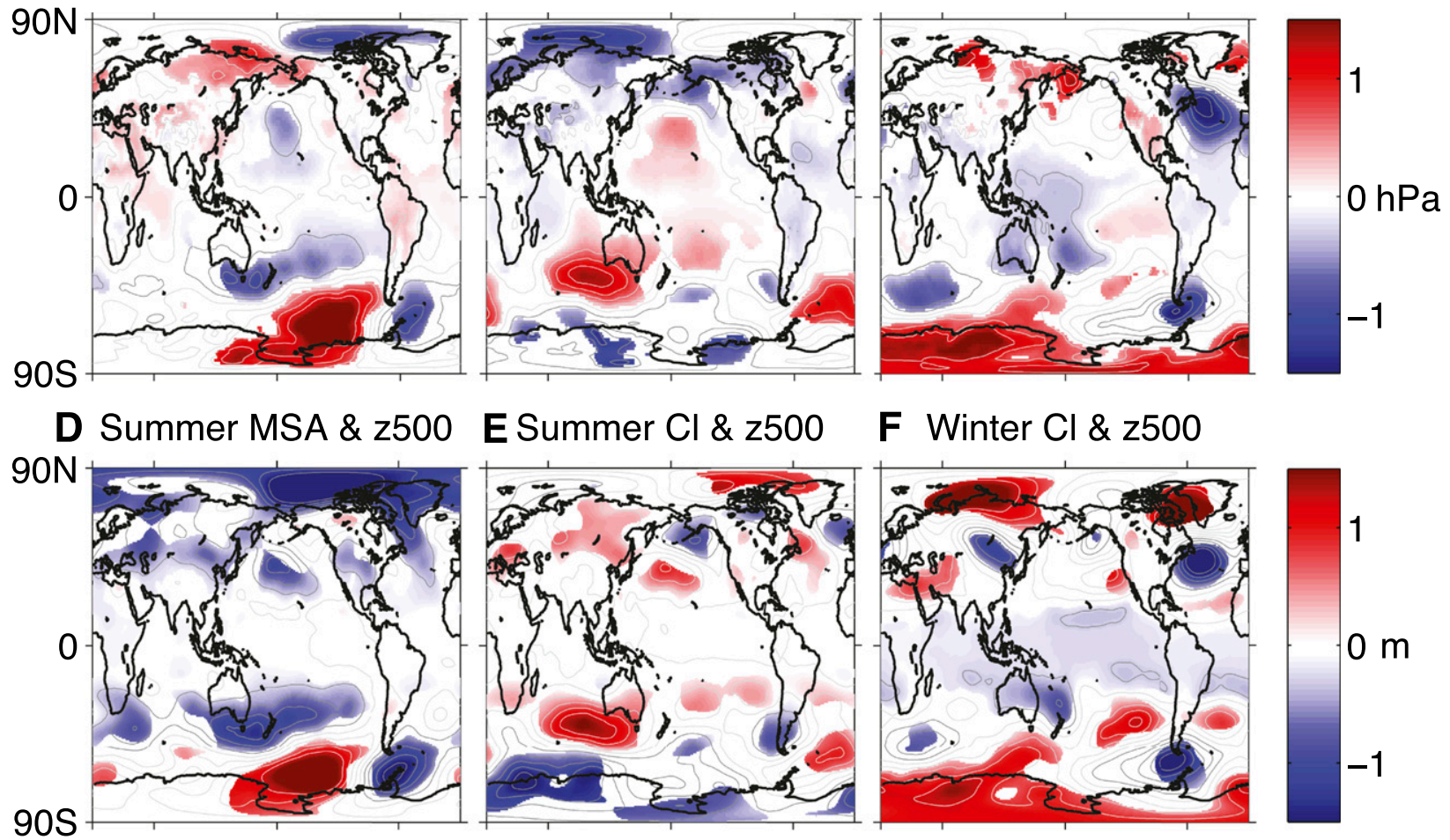

\section{F Winter Cl \& z500}
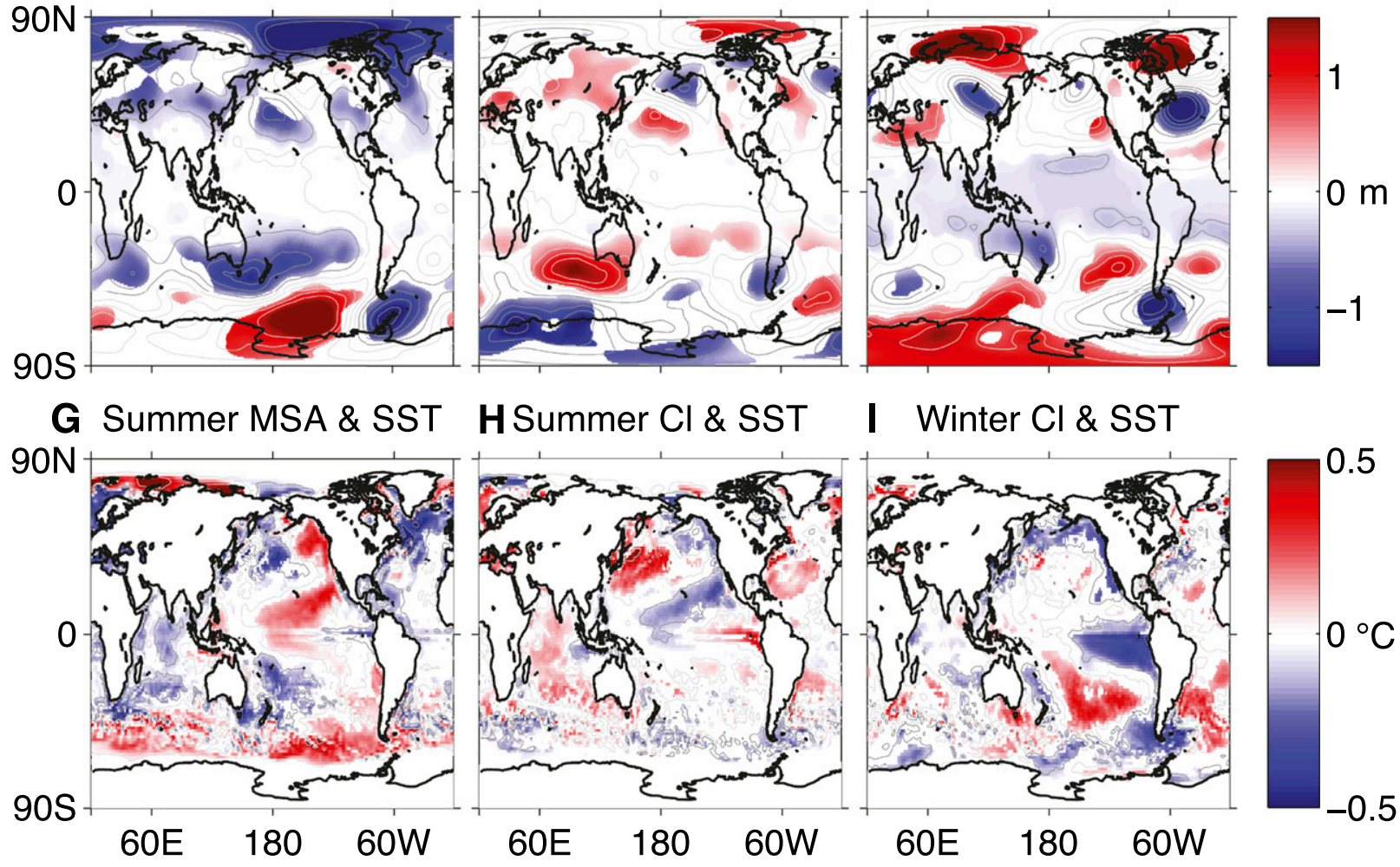

FIG. 4. PIG2010 regression maps (1992-2010) of summer (November-March) (a) SLP, (d) 500-hPa GH, and (g) SST on summer MSA; summer (b) SLP, (e) 500-hPa GH, and (h) SST on summer $\mathrm{Cl}^{-}$; and winter (June-October) (c) SLP, (f) 500-hPa GH, and (i) SST on winter $\mathrm{Cl}^{-}$. The SLP scale is from -1.5 to $1.5 \mathrm{hPa}$ (with $0.3-\mathrm{hPa}$ contours), the $500-\mathrm{hPa}$ GH scale is from -1.5 to $1.5 \mathrm{~m}$ (with $0.3-\mathrm{m}$ contours), and the SST scale is from $-0.5^{\circ}$ to $0.5^{\circ} \mathrm{C}$ (with $0.4^{\circ} \mathrm{C}$ contours). Contours show all regression patterns (no threshold of statistical significance; positive contours in light gray, negative contours in dark gray), while shaded regions indicate $>95 \%$ significance (determined using a twotailed Student's $t$ test; positive shaded in red, negative shaded in blue).

500-hPa GH on MSA are the only regressions that show low pressure over the entire polar region (indicative of the positive phase of SAM), whereas the winter regressions of SLP and $500-\mathrm{hPa} \mathrm{GH}$ on $\mathrm{Cl}^{-}$show a similar Rossby wave pattern as seen at DIV2010 and PIG2010 but of opposite sign (Fig. 6). At UPT2009, regressions of SLP and 500-hPa GH (Fig. 7) on summer MSA and winter $\mathrm{Cl}^{-}$show a Rossby wave pattern similar to the winter regression at THW2010 (with a high pressure anomaly centered near the Amundsen Coast and the western Antarctic Peninsula). Regressions using SLP and 500-hPa GH are similar to one another in pattern outside the tropics, and both are significant at $p<0.05$, but regions of statistical significance tend to be larger and more coherent at $500 \mathrm{hPa}$, that is, in the free troposphere (indicated by shading in Figs. 4-7). 
A Summer MSA \& SLP
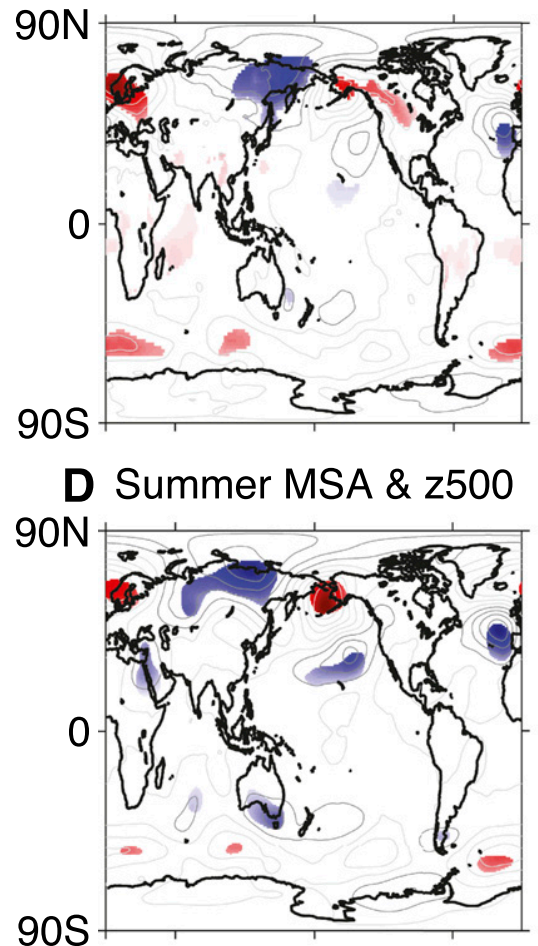

\section{G Summer MSA \& SST} $90 \mathrm{~N}$

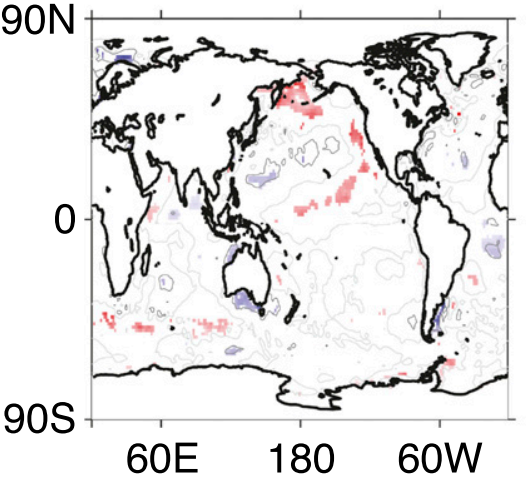

B Summer Cl \& SLP

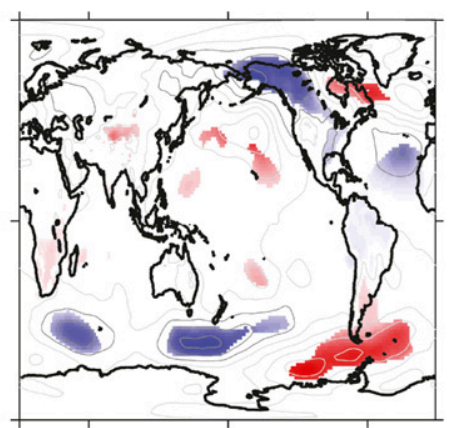

ESummer Cl \& z500
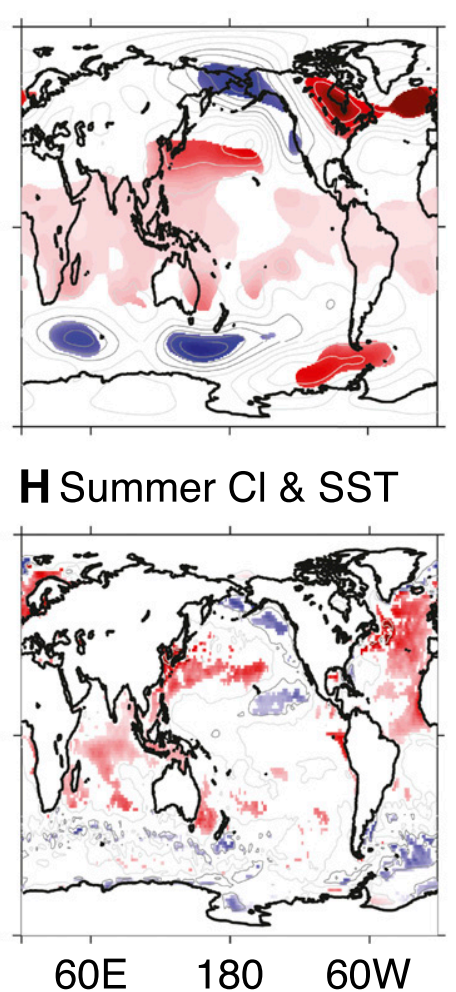

C Winter Cl \& SLP

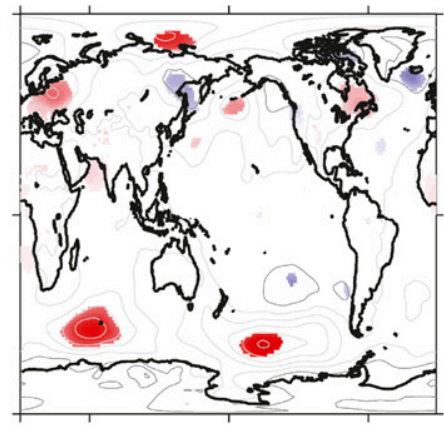

F Winter Cl \& z500

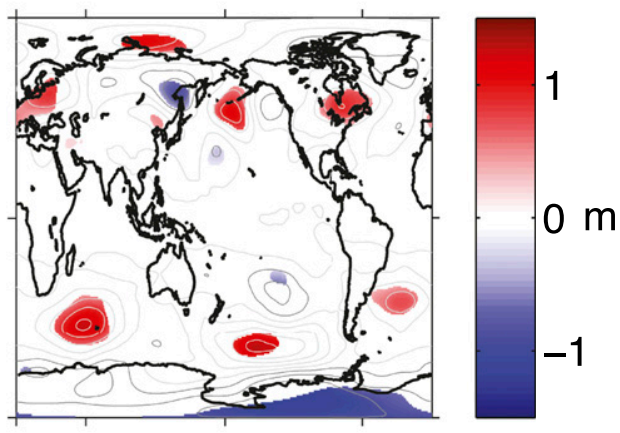

I Winter Cl \& SST

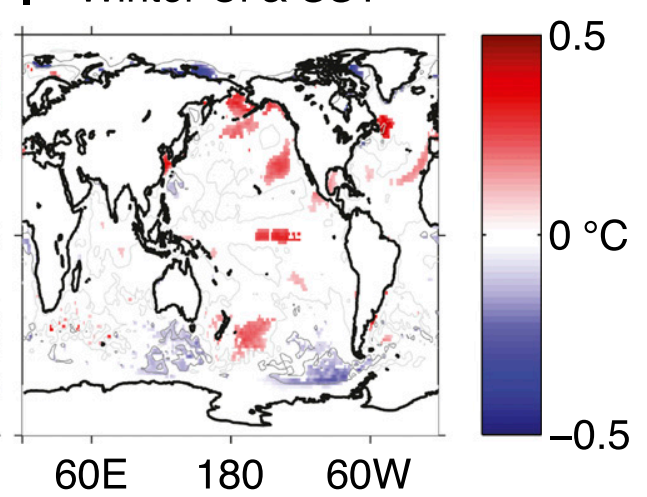

FIG. 5. As in Fig. 4, but for DIV2010 and the period 1979-2010.

A similar hemispheric-scale pattern is found in regressions of SLP or 500-hPa GH on TOWA (not statistically significant at $p<0.05$; Fig. 8) and regional SIE (statistically significant at $p<0.05$; Fig. 9), where the regional SIE exhibits a distinct SAM-like pattern with a wave train embedded, particularly in winter (see also Figs. S5 and S6 in the supplemental material). The alternating low and high pressure anomalies at both the surface as well as throughout the atmospheric column suggest a barotropic response of the atmosphere connecting the western tropical Pacific with the Antarctic Peninsula (Trenberth et al. 1998). These global regression fields of atmospheric variability on firn-core records are evident year-round, but are generally stronger in winter (as seen in the $\mathrm{Cl}^{-}$and SIE regressions; Figs. 4-7 and 9). We note that significant regressions present in some cases in the equatorial and South Atlantic basin are not discussed here, as they are a result of the fast tropical atmospheric adjustment (Matsuno 1966; Gill 1980). Regressions at high north and south latitudes are often similar in strength and pattern (e.g., UPT2009 summer MSA and SLP; Fig. 7a). It is encouraging that the significant regressions in the $\mathrm{SH}$ are mirrored in the Northern Hemisphere, as this provides additional evidence of the tropical Pacific influence on both hemispheres (e.g., 


\section{A Summer MSA \& SLP B Summer Cl \& SLP C Winter Cl \& SLP}
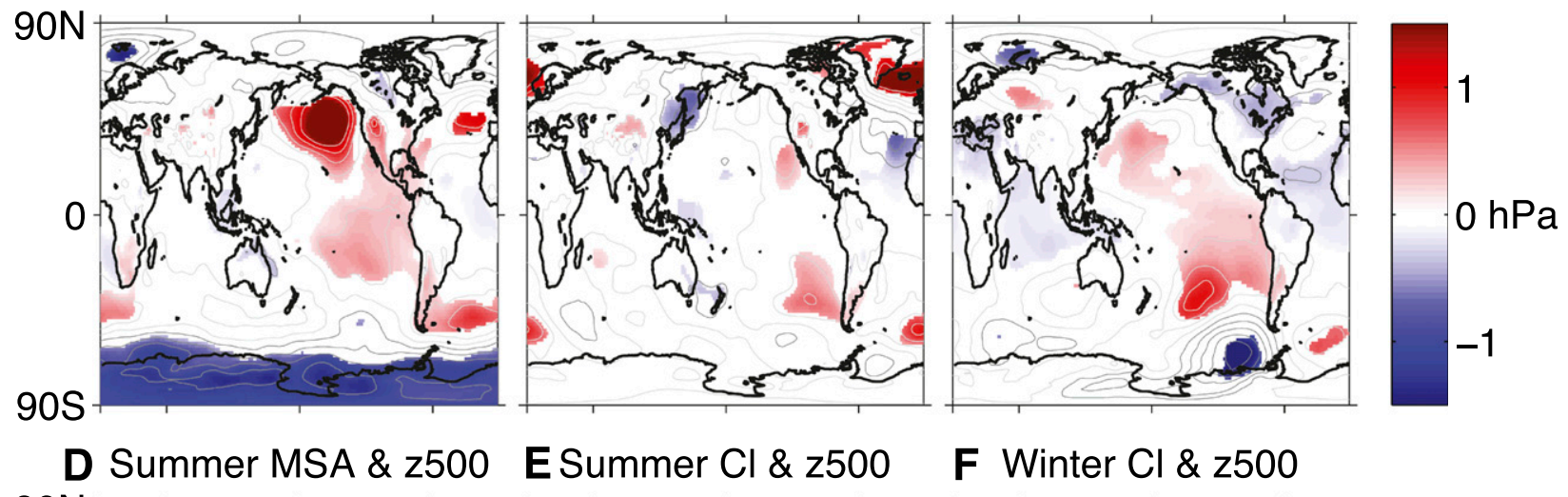

\section{F Winter $\mathrm{Cl} \& \mathrm{z} 500$}
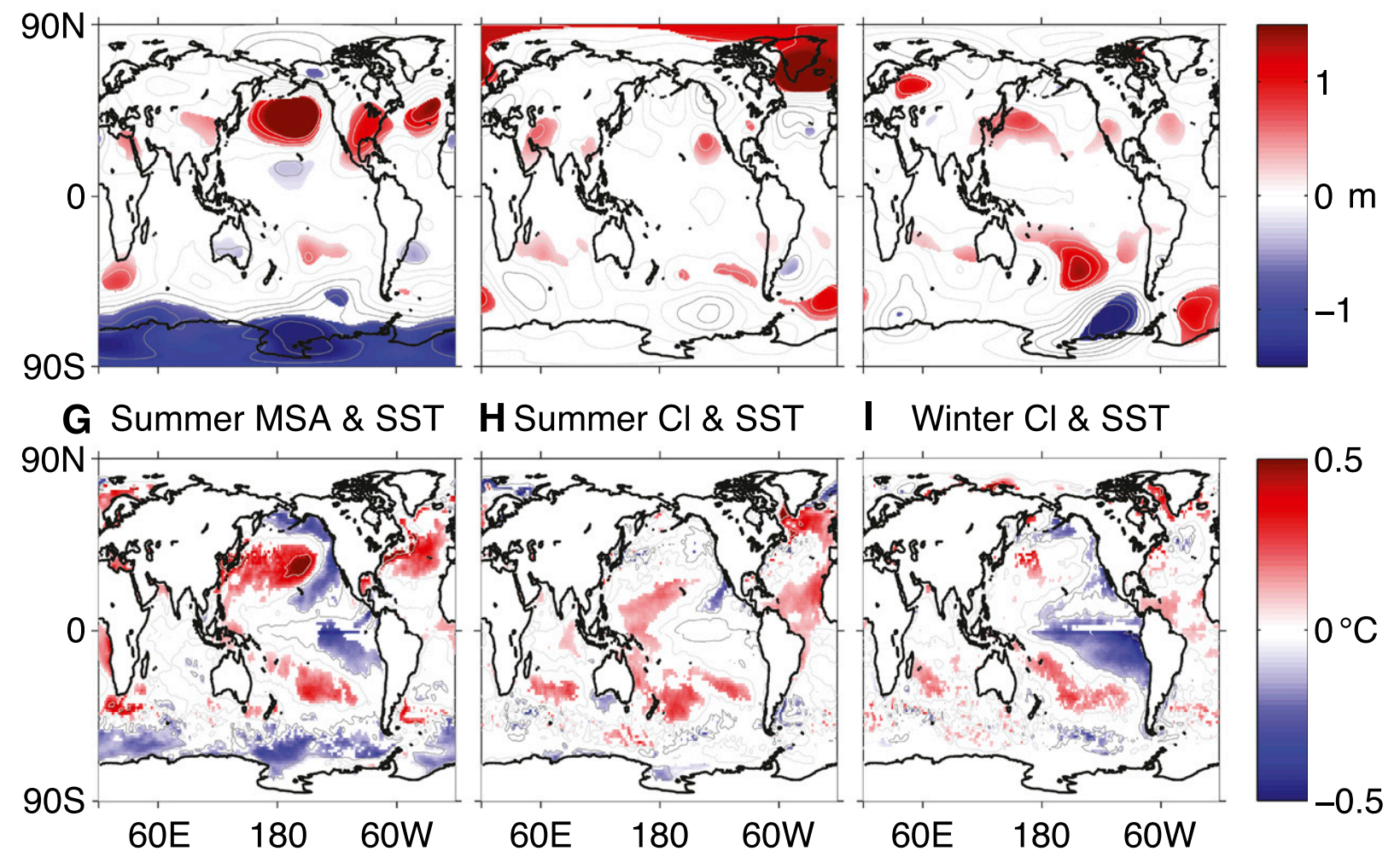

FIG. 6. As in Fig. 4, but for THW2010 and the period 1979-2010.

Trenberth et al. 1998; Lee et al. 2011; and references therein).

\section{c. Global SST anomalies}

Regressions of SST on the marine aerosol records at some sites reveal a strong Antarctic connection to SST anomalies in the equatorial Pacific. This is in agreement with the initiation and propagation of a Rossby wave train (Hoskins and Karoly 1981; Jin and Hoskins 1995; Zhang et al. 1997) as revealed by the SLP and 500-hPa GH analyses described in section 3 above. UPT2009 (Fig. 7) summer and winter $\mathrm{Cl}^{-}$, as well as PIG2010 (Fig. 4) summer $\mathrm{Cl}^{-}$, are positively correlated with SST in the eastern tropical Pacific. PIG2010 summer MSA and winter $\mathrm{Cl}^{-}$, and THW2010 summer MSA and winter $\mathrm{Cl}^{-}$, are negatively correlated with SST in the eastern tropical Pacific (La Niña-like conditions). The most significant and organized patterns of SST regressions in the equatorial Pacific are on winter $\mathrm{Cl}^{-}$at PIG2010 and THW2010 (Figs. 4 and 6; see also Figs. S3d and S3f in the supplemental material). Similarly, the summer and winter regional SIE time series are negatively correlated with SST in the eastern tropical Pacific (Fig. 9; see also Fig. S6c). The THW2010 regressions of SST on MSA and $\mathrm{Cl}^{-}$anomalies show a horseshoe pattern in the North Pacific (the highest elevation site; Fig. 6). A 
A Summer MSA \& SLP
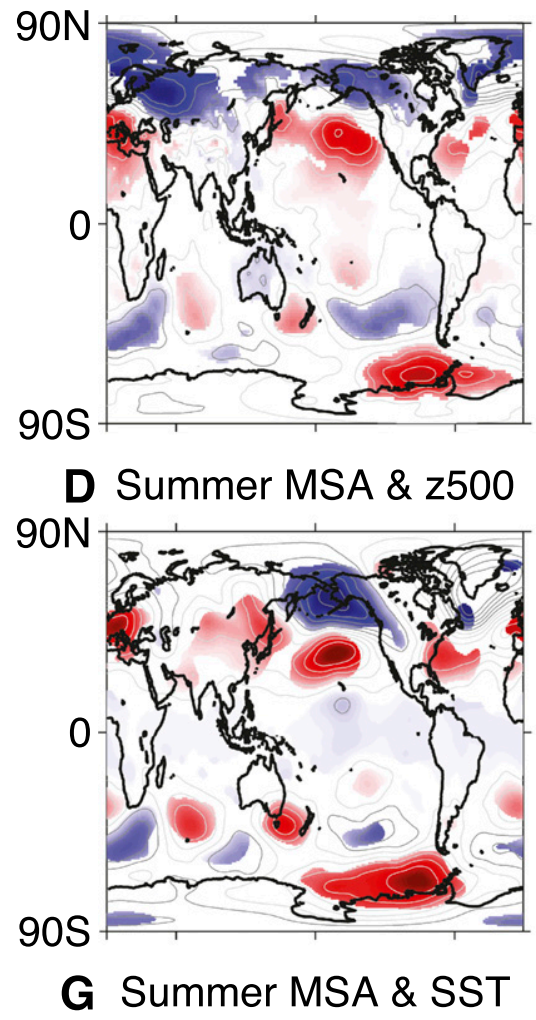

\section{$90 \mathrm{~N}$}

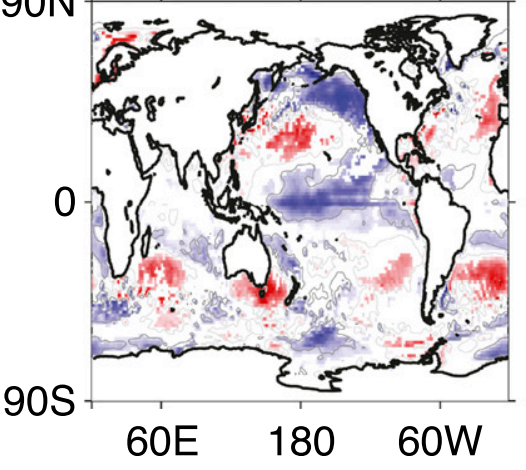

B Summer Cl \& SLP

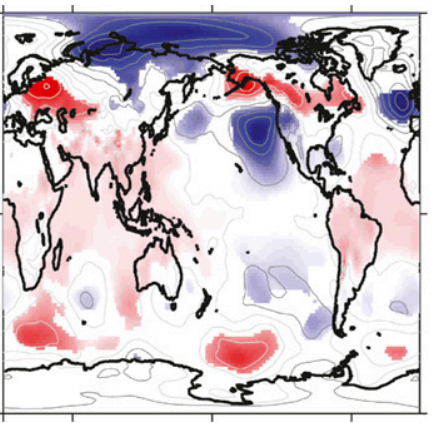

ESummer Cl \& z500
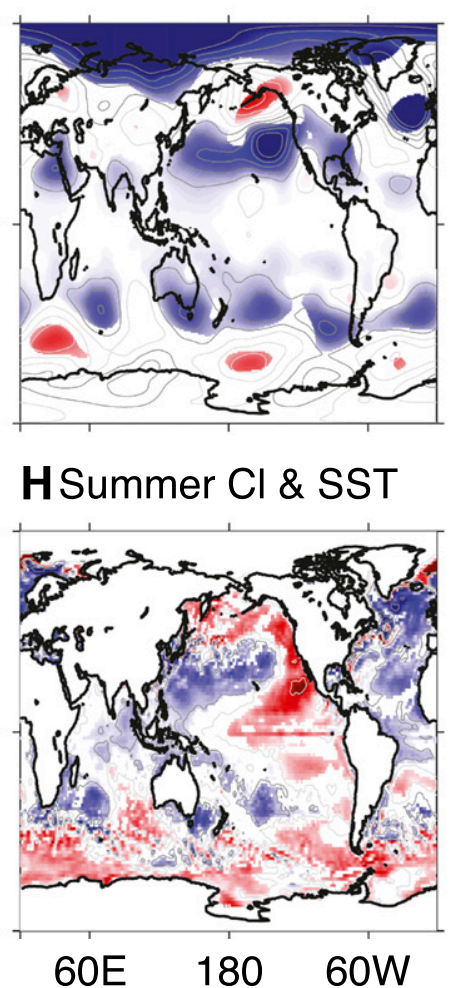

C Winter $\mathrm{Cl} \&$ SLP

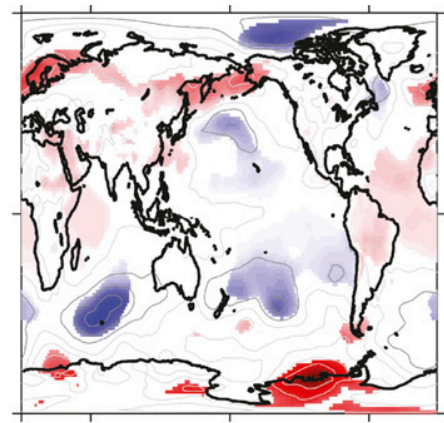

F Winter $\mathrm{Cl} \&$ z500

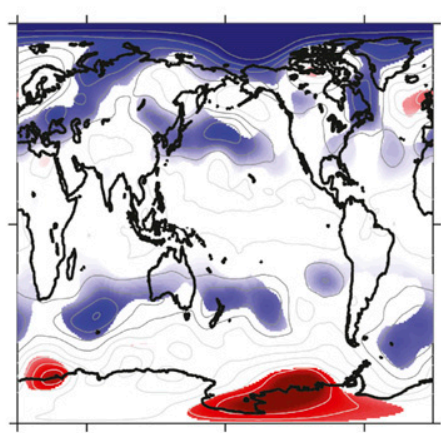

I Winter Cl \& SST

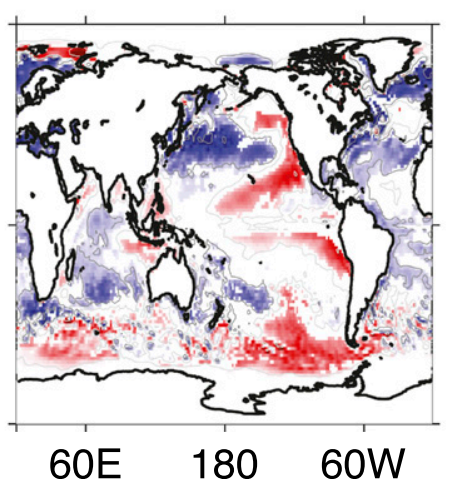

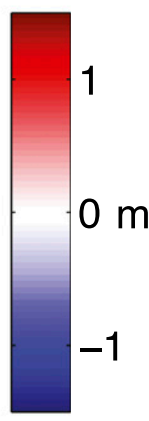
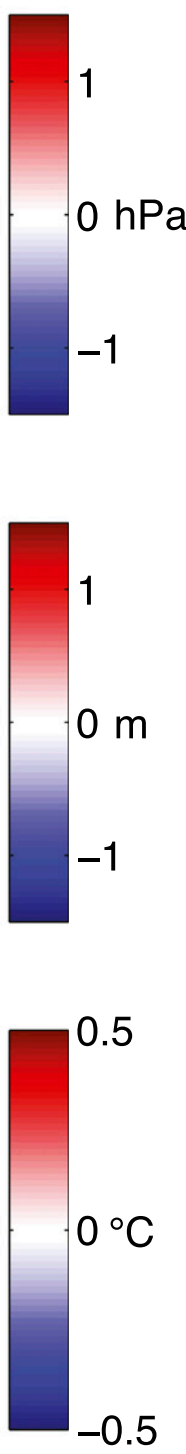

FIG. 7. As in Fig. 4, but for UPT2009 and the period 1992-2009.

horseshoe pattern of opposite sign in the North Pacific is seen for summer MSA at PIG2010 (Fig. 4) and summer and winter $\mathrm{Cl}^{-}$at UPT2009 (Fig. 7). There is less variability in SST in the tropics than at high latitudes; therefore, the SST patterns we do see in the tropics are particularly notable.

\section{d. Regional wind variability}

At all sites, regression of summer surface wind velocity on summer MSA highlights offshore wind anomalies within Pine Island Bay and along the Amundsen Coast (Fig. 10; see also Fig. S4). The same relationship is found between summer TOWA and summer winds
(Fig. 8d; see also Fig. S5d), and winter regional SIE and winter winds (Fig. 9h; see also Fig. S6d). At DIV2010 (the lowest elevation site, closest to Pine Island Bay), regressions of summer and winter surface wind velocity on summer and winter $\mathrm{Cl}^{-}$also show offshore wind anomalies along the Amundsen Coast, similar to the pattern observed at this site with summer MSA (Figs. 10b,c). At PIG2010, regression of summer surface wind velocity on summer $\mathrm{Cl}^{-}$shows easterly wind anomalies within Pine Island Bay (Fig. 10e). At PIG2010 and UPT2009 (the sites farthest from the coast), regression of winter surface wind velocity on winter $\mathrm{Cl}^{-}$shows an opposite pattern to MSA, with onshore wind anomalies 

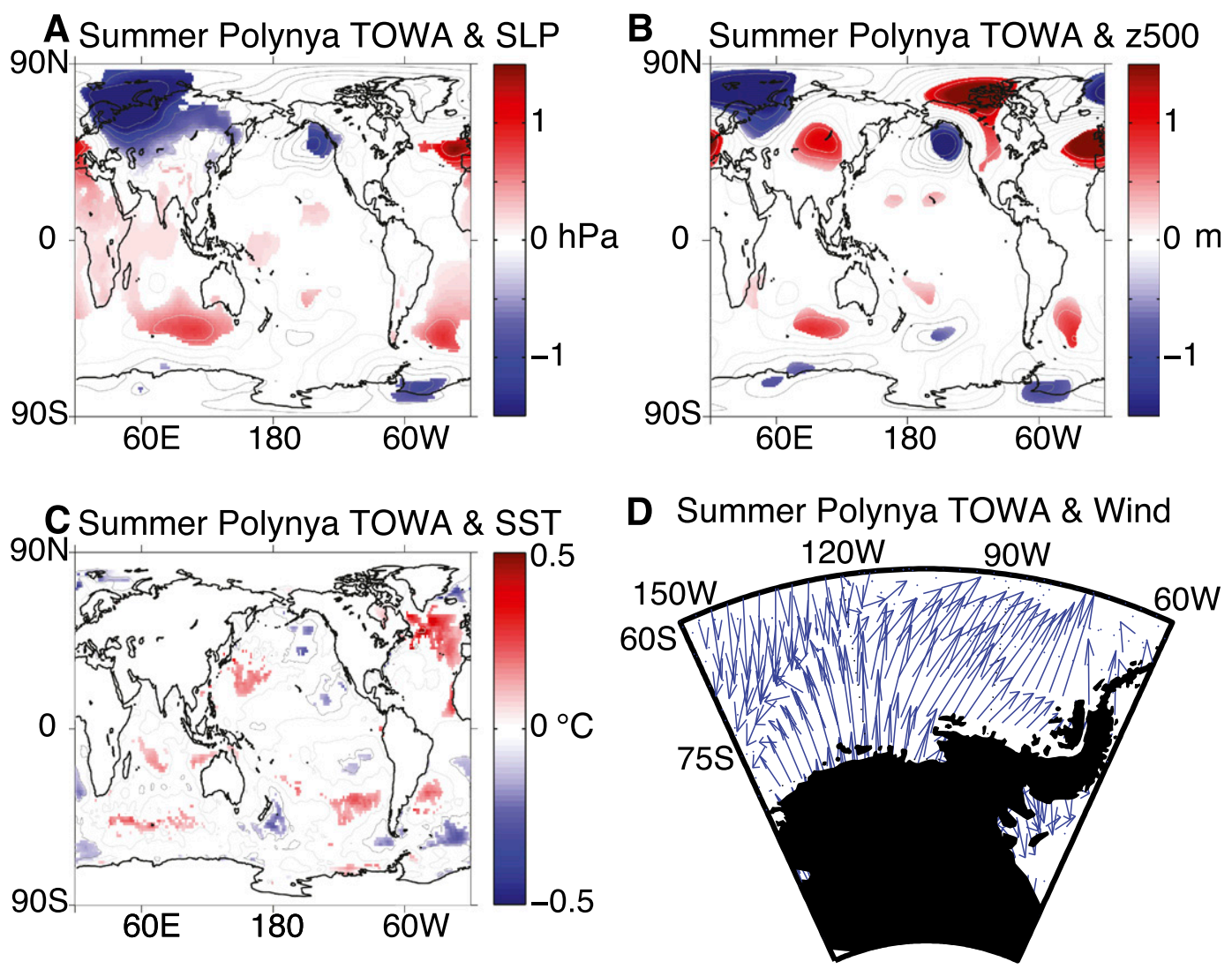

FIG. 8. Regression maps of summer (November-March) (a) SLP, (b) 500-hPa GH, (c) SST, and (d) wind on regional summer polynya total open water area (TOWA). The SLP scale is from -1.5 to $1.5 \mathrm{hPa}$ (with $0.3-\mathrm{hPa}$ contours), the $500-\mathrm{hPa} \mathrm{GH}$ scale is from -1.5 to $1.5 \mathrm{~m}$ (with $0.3-\mathrm{m}$ contours), and the SST scale is from $-0.5^{\circ}$ to $0.5^{\circ} \mathrm{C}$ (with $0.4^{\circ} \mathrm{C}$ contours). Contours show all regression patterns (no threshold of statistical significance; positive contours in light gray, negative contours in dark gray), while shaded regions indicate $>95 \%$ significance (determined using a two-tailed Student's $t$ test; positive shaded in red, negative shaded in blue). The average arrow length represents on the order of approximately $10 \mathrm{~m} \mathrm{~s}^{-1}$.

within Pine Island Bay and along the Amundsen Coast (Figs. 10f,1). At THW2010, regression of summer surface wind velocity on summer $\mathrm{Cl}^{-}$shows neutral wind anomalies within Pine Island Bay, and onshore wind anomalies along the Amundsen Coast (Fig. 10h); regression of winter surface wind velocity on winter $\mathrm{Cl}^{-}$ shows onshore wind anomalies within Pine Island Bay and neutral wind anomalies along the Amundsen Coast (Fig. 10i).

\section{Discussion}

In this section we discuss the broad seasonal relationships between regional wind anomalies and the source and transport of marine biogenic and sea-salt aerosols to the ice sheet indicated by our results above. Within that context, we take advantage of our records from multiple core sites to begin to assess how locations across the Amundsen catchment of WAIS are impacted spatially in response to atmospheric transport and marine aerosol source variability. Finally, we discuss the $\mathrm{SH}$ teleconnection to the tropical Pacific in the context of these new ice-sheet records from along the Amundsen Coast.

\section{a. Regional wind anomalies and marine biogenic aerosol source and transport}

The strong annual cycle of MSA shown at all sites (Fig. 3) supports previous findings that the marine biogenic compounds in ice cores from this region are derived primarily from summer productivity in the sea ice zone of the Amundsen Sea, with particularly strong influence from seasonal sea ice loss within the Pine Island Bay and Amundsen Sea polynyas for the most coastal ice-core sites (Criscitiello et al. 2013). Records from other Antarctic locations indicate negative correlations between MSA concentrations and SIE more broadly, consistent with the source of MSA being derived largely 
A Summer SIE \& SLP

$90 \mathrm{~N}$

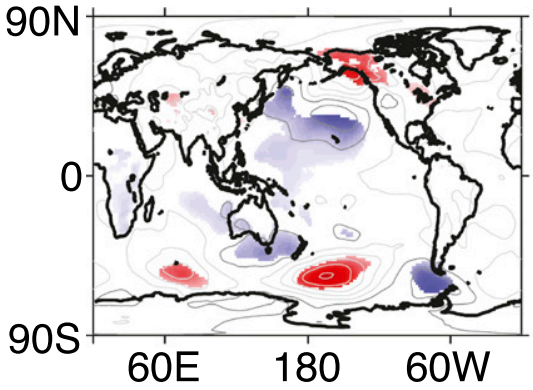

C Summer SIE \& z500

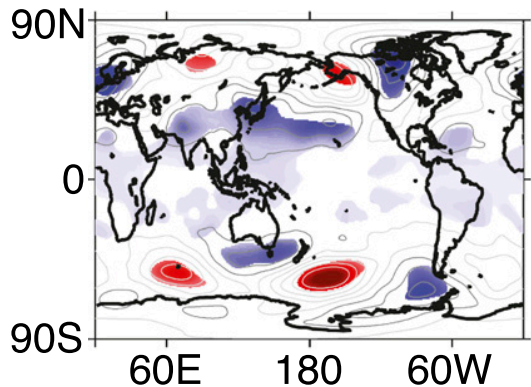

\section{E Summer SIE \& SST}

$90 \mathrm{~N}$

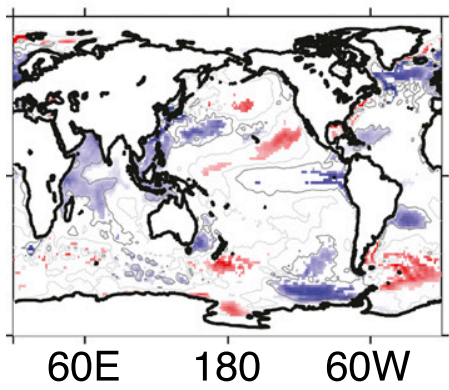

G Summer SIE \& Wind

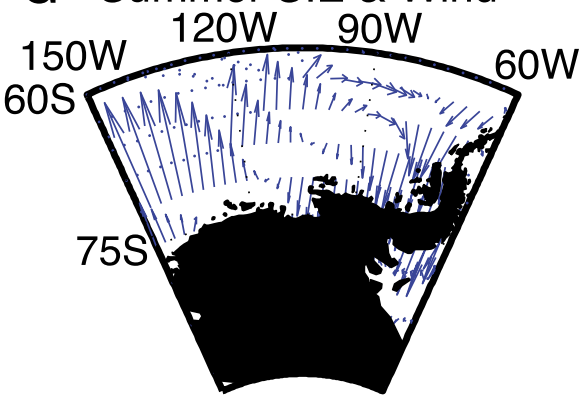

B Winter SIE \& SLP

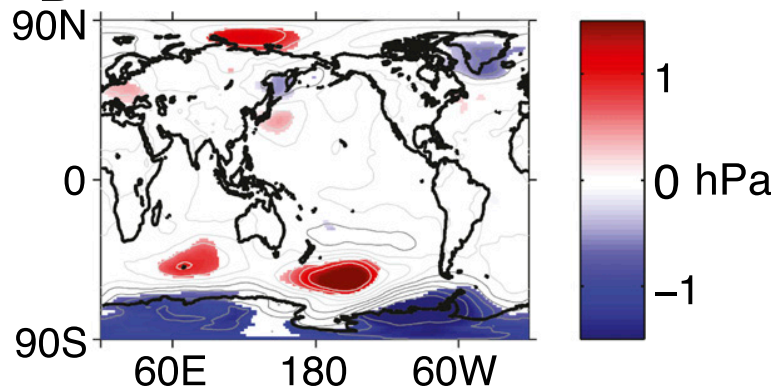

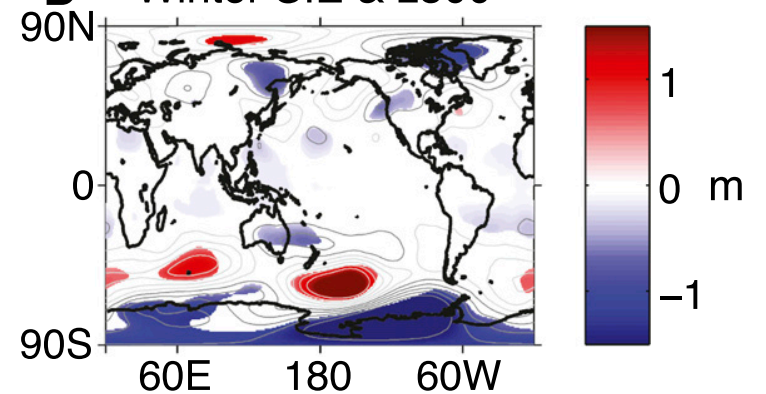

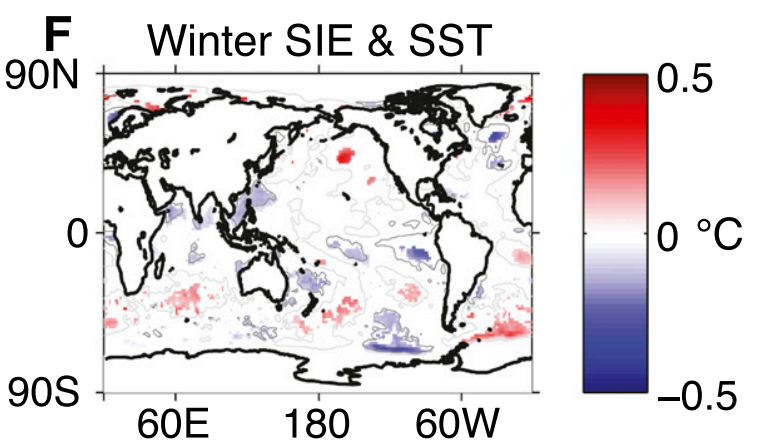

H Winter SIE \& Wind

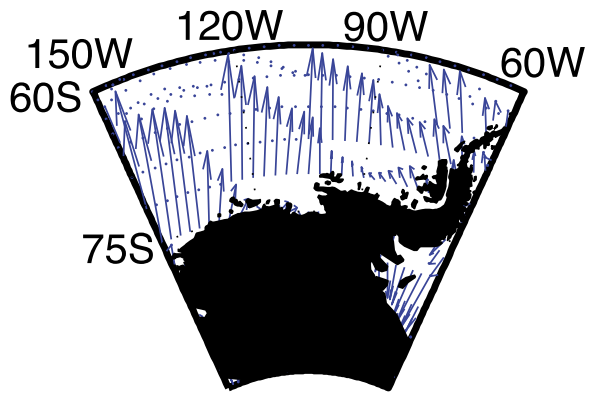

FIG. 9. Regression maps of summer (November-March) (a) SLP, (c) 500-hPa GH, (e) SST, and (g) wind on regional SIE (for the region between $80^{\circ}-140^{\circ} \mathrm{W}$ and $60^{\circ}-71^{\circ} \mathrm{S}$ ) and winter (June-October) (b) SLP, (d) $500-\mathrm{hPa} \mathrm{GH}$, (f) SST, and (h) wind on winter SIE. The SLP scale is from -2 to $2 \mathrm{hPa}$ (with 0.3 -hPa contours), the $500-\mathrm{hPa}$ GH scale is from -2 to $2 \mathrm{~m}$ (with $0.3-\mathrm{m}$ contours), and the SST scale is from $-0.5^{\circ}$ to $0.5^{\circ} \mathrm{C}$ (with $0.2^{\circ} \mathrm{C}$ contours). Contours show all regression patterns (no threshold of statistical significance; positive contours in light gray, negative contours in dark gray), while shaded regions indicate $>95 \%$ significance (determined using a two-tailed Student's $t$ test; positive shaded in red, negative shaded in blue). The average arrow length represents on the order of approximately $10 \mathrm{~m} \mathrm{~s}^{-1}$. 
DIV2010 Summer MSA \& Winds

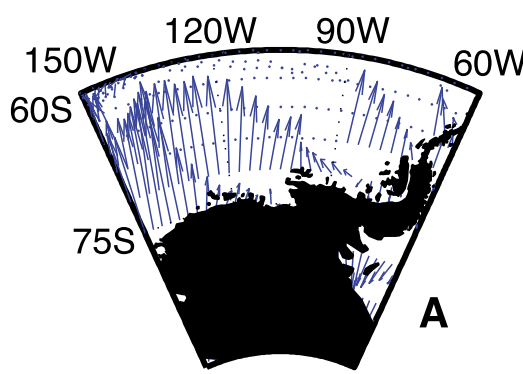

PIG2010 Summer MSA \& Winds

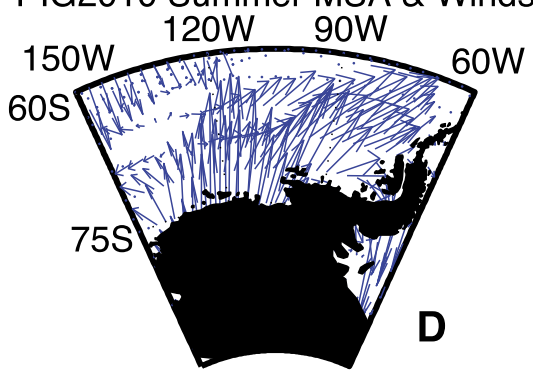

THW2010 Summer MSA \& Winds

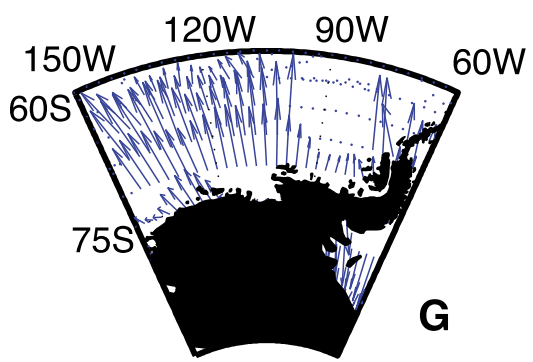

UPT2009 Summer MSA \& Winds

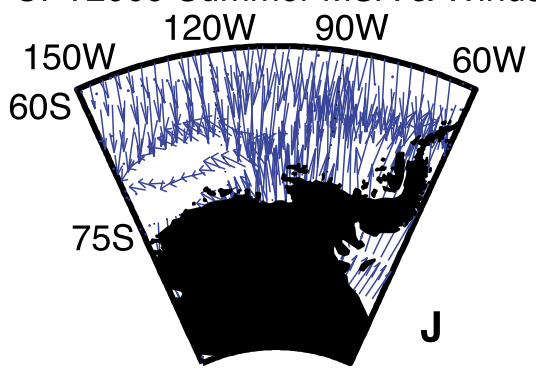

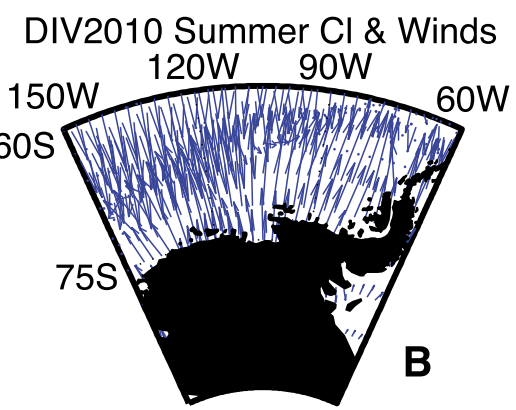

PIG2010 Summer $\mathrm{Cl}$ \& Winds

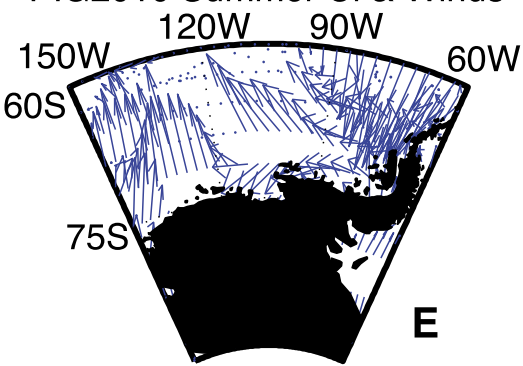

THW2010 Summer Cl \& Winds

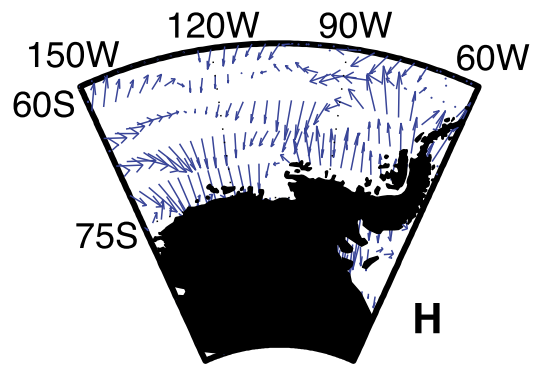

UPT2009 Summer CI \& Winds

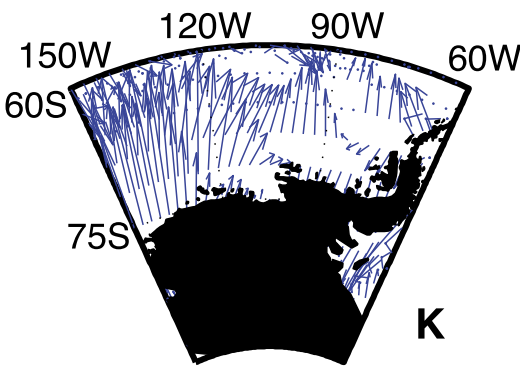

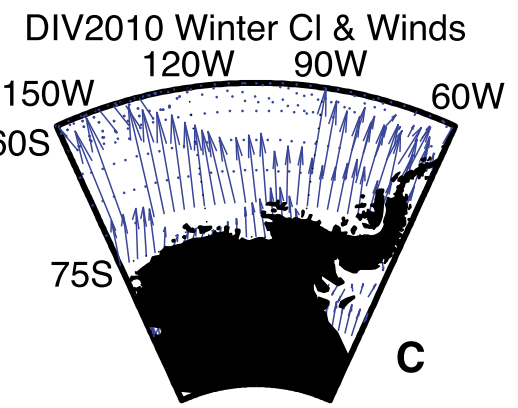

PIG2010 Winter $\mathrm{Cl} \&$ Winds

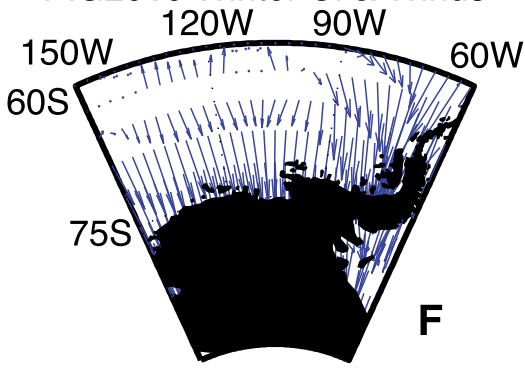

THW2010 Winter Cl \& Winds

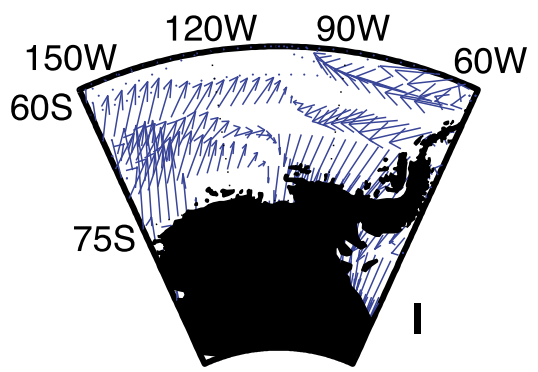

UPT2009 Winter Cl \& Winds

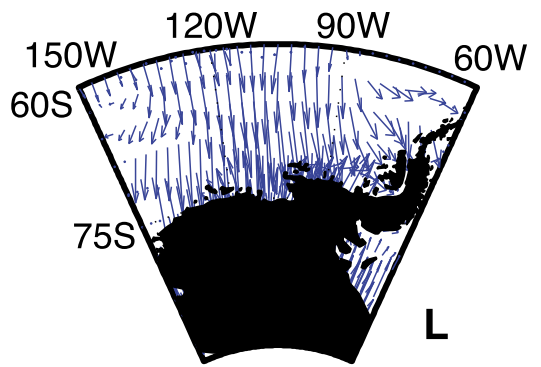

FIG. 10. Regression of summer (November-March) wind on summer MSA at (a) DIV2010, (d) PIG2010, (g) THW2010, and (j) UPT2009, summer wind on summer $\mathrm{Cl}^{-}$at (b) DIV2010, (e) PIG2010, (h) THW2010, and (k) UPT2009, and winter (June-October) wind on winter $\mathrm{Cl}^{-}$at (c) DIV2010, (f) PIG2010, (i) THW2010, and (l) UPT2009. The average arrow length represents on the order of approximately $10 \mathrm{~m} \mathrm{~s}^{-1}$.

from summer productivity following sea ice breakup (Pasteur et al. 1995; Abram et al. 2007; Rhodes et al. 2009; Abram et al. 2011). The deposition of MSA on the ice sheet requires both conditions favorable for phytoplankton blooms as well as effective atmospheric transport of the resulting marine biogenic species onshore.
Our results show that during times of MSA deposition, offshore wind anomalies (weakened onshore winds) are prevalent. We suggest that this anomaly increases both MSA source and transport through a proposed link with regional katabatic winds and associated polynya behavior (Fig. 11); this phenomenon is best expressed at DIV2010, 
A
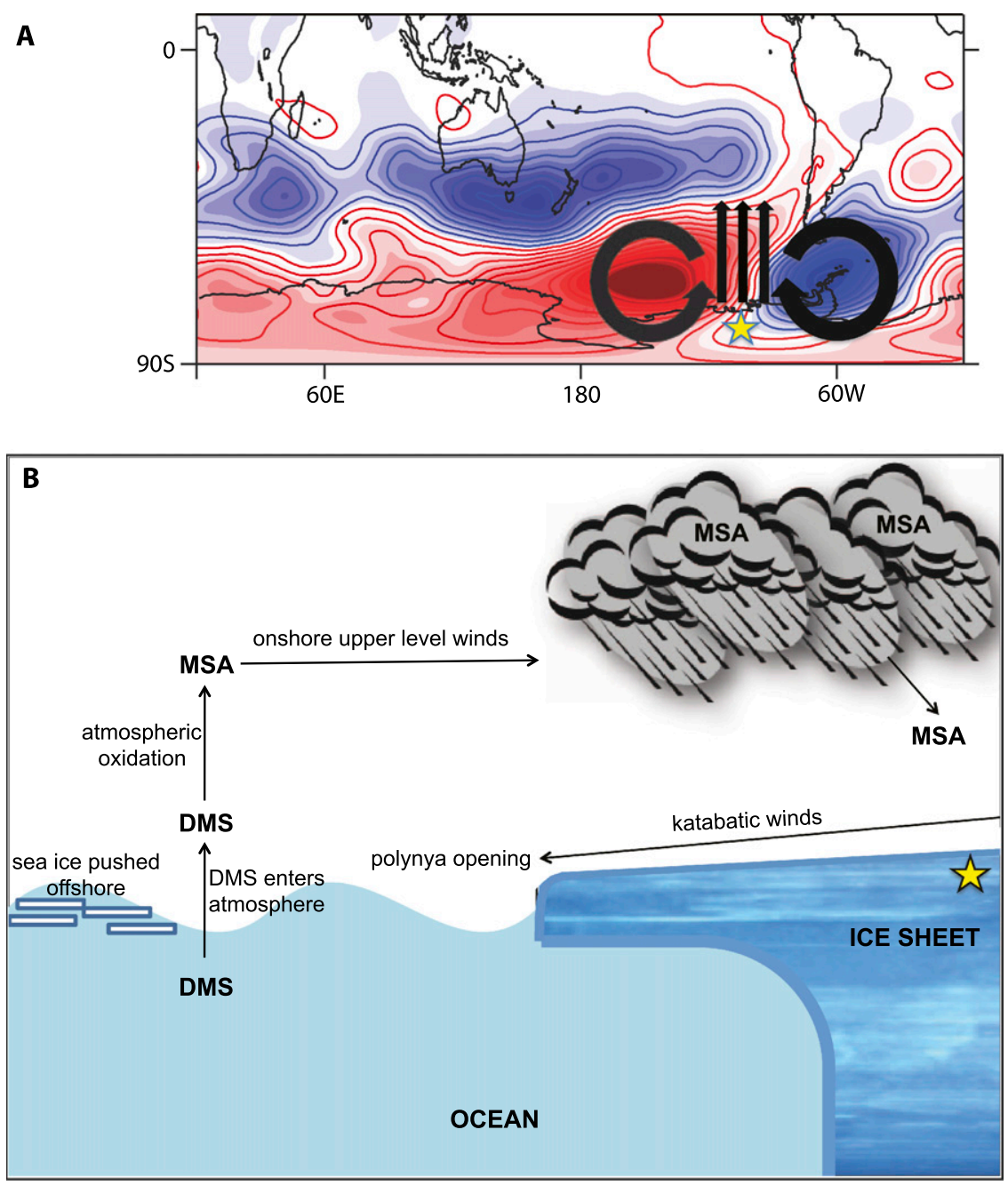

FIG. 11. (a) Schematic map view of regional-scale circulation and winds during high summertime MSA deposition at DIV2010. Low pressure (cool colors) over the Antarctic Peninsula results in clockwise wind anomalies, while high pressure (warm colors) west of Pine Island Bay results in counterclockwise wind anomalies. The result is strong offshore wind anomalies on the ice sheet near Pine Island Bay (indicated by yellow star). (b) Schematic side-view of the same ice-sheet location (yellow star), highlighting local dynamics associated with large-scale teleconnections. Katabatic winds flow off the ice sheet, opening the polynyas and allowing for DMS production. DMS is oxidized in the atmosphere to MSA, which is transported over the ice sheet by onshore upper-level winds and precipitated on the ice sheet. While offshore wind anomalies are associated with MSA deposition at all sites, this schematic most directly represents dynamics at DIV2010, the most coastal site.

the most coastal site. Additionally, these offshore wind anomalies may contribute to sea ice breakup and thus enhanced DMS production near the leading ice edge, impacting the MSA record over parts of the ice sheet that receive precipitation from moisture source regions farther offshore. The reduced onshore winds observed during times of MSA deposition described above are in agreement with transport of marine biogenic aerosols to the ice sheet, as the climatology confirms that winds are consistently onshore during MSA deposition at all sites, which is necessary for transmission of moisture to the ice sheet (precipitation being the source of the marine signal; Fig. 11).

Previous work has shown that this region experiences persistent, strong katabatic winds (Parish and Bromwich 1987), which can develop more easily when there is a reduction in onshore winds (Nylen et al. 2004). Furthermore, katabatic winds have been shown to produce favorable conditions for polynya openings generally (Marshall and Turner 1997) and along the Amundsen 
Coast more specifically (Arrigo et al. 2012). Along the Amundsen Coast, katabatic winds push higher than normal volumes of sea ice both northward in the Amundsen Sea and away from the coast, yielding persistent polynya formation and resulting in high primary production rates (Smith et al. 2000; Arrigo and van Dijken 2003) and strong air-sea heat fluxes (Fusco et al. 2009). Katabatic winds are not captured by the reanalysis data employed in this study, so we cannot use the present study to test this hypothesis directly, but as detailed above the broad existing knowledge available about katabatic dynamics in this region supports this scenario, particularly for DIV2010, the most coastal site (Fig. 11).

We find that PIG2010 and THW2010 have the highest composite summer MSA concentrations and strongest seasonal cycles (Fig. 3). PIG2010 has offshore wind anomalies in Pine Island Bay and along the leading ice edge in the Amundsen Sea during MSA deposition in summer (Fig. 10d), which indicate that Pine Island Bay (and the polynyas) as well as the leading ice edge in the Amundsen Sea are source regions of marine biogenic aerosols to this site. THW2010 has offshore summer wind anomalies along the central Amundsen Coast during times of MSA deposition (Fig. 10g), and is situated geographically closest to the highly productive Amundsen Sea polynya. These results indicate that the Amundsen Sea polynya is a source region of marine biogenic aerosols to THW2010. The particularly high MSA concentrations at these two sites, situated near ice divides, could also be indicative of their receiving MSA from multiple nearby source regions. Of all four sites, PIG2010 is located the farthest east along the Amundsen Coast, and receives moisture both from the Amundsen-Bellingshausen Sea and the Weddell Sea [as has been previously shown by Kaspari et al. (2005) for the nearby International Trans-Antarctic Scientific Expedition (ITASE) site 01-3; Fig. 1]. Similarly, THW2010 likely receives moisture from the Amundsen-Bellingshausen Sea and the Ross Sea because of its location between these two catchments [similar to the findings by Kaspari et al. (2005) for the nearby ITASE $00-4$ and $00-5$ sites located on the Ross side of this divide; Fig. 1]. Polynyas in the Weddell and Ross Seas have been previously shown to contribute to marine aerosol records in coastal Antarctic ice cores (Barber and Massom 2007, and references therein), and the Bellingshausen Sea polynyas likely do as well.

DIV2010 has relatively high composite summer MSA concentrations (comparable to THW2010; Fig. 3) and has offshore wind anomalies along the Amundsen Coast, within Pine Island Bay, and near the leading ice edge in the Amundsen Sea during times of MSA deposition
(Fig. 10a). These results indicate that, likely due in part to its location closest to Pine Island Bay, both nearshore regions such as the polynyas as well as offshore regions near the leading ice edge in the Amundsen Sea are source regions of MSA to DIV2010. In contrast to the other three sites, UPT2009 has both considerably lower composite summer MSA concentrations and the least pronounced seasonal cycle of all four core sites (Fig. 3). Results from this site show offshore summer wind anomalies within Pine Island Bay, and easterly convergent wind anomalies along the Amundsen Coast and near the leading ice edge in the Amundsen Sea during high MSA deposition (Fig. 10j). These results show that UPT2009 is subject to both limited MSA source regions (primarily the leading ice edge in the Amundsen Sea) and decreased transport of MSA, likely a result of its location (farthest inland and at a relatively high elevation).

\section{b. Regional wind anomalies and sea-salt source and transport}

The annual cycle of $\mathrm{Cl}^{-}$shown at all sites (Fig. 3) supports previous findings that sea salts in cores from this region are derived largely from winter sea ice formation, although sea salts are deposited year-round. This sea ice formation occurs within the polynyas, across the Amundsen Coast continental shelf break, and in other regions in the Amundsen Sea north of $70^{\circ} \mathrm{S}$ inferred to be the leading ice edge during the period of fall sea ice formation (Criscitiello et al. 2013). Akin to the discussion of MSA above, the deposition of sea salts onto the ice sheet requires conditions favorable for sea ice formation, as well as effective atmospheric transport of the resulting sea-salt aerosols to the ice sheet.

Comparison of results from the four different core sites highlights the importance of regional differences in sea-salt source and transport to any one specific icesheet location. DIV2010 has the second highest composite winter $\mathrm{Cl}^{-}$concentrations (Fig. 3) and is the only site with offshore summer and winter wind anomalies associated with enhanced sea-salt deposition (Figs. 10b,c). These results suggest that polynyas and other local nearshore areas in the Amundsen Sea sea ice zone may be a larger source of $\mathrm{Cl}^{-}$to DIV2010 than at the other core sites, likely resulting from its proximity to Pine Island Bay. PIG2010 and THW2010 have the lowest composite winter $\mathrm{Cl}^{-}$concentrations (Fig. 3). PIG2010 has winter onshore wind anomalies originating from the Amundsen Sea (strong meridional winds) during times of winter $\mathrm{Cl}^{-}$ deposition, which may account for the low wintertime $\mathrm{Cl}^{-}$concentrations at this site. Previous work at the nearest ITASE site to PIG2010 (ITASE 01-3; Fig. 1) suggests that blocking by katabatic winds and "blocking-high 
effects" (Massom et al. 2004) may inhibit sea-salt deposition at this location (Kaspari et al. 2005). THW2010 has onshore wind anomalies along the Amundsen Coast in summer, and onshore wind anomalies near Pine Island Bay in winter, which are part of a low pressure system with an offshore limb over the Ross sector, during times of high $\mathrm{Cl}^{-}$deposition (Figs. 10h,i). As discussed above, this site has more than one moisture source region. Previous evidence has shown that core sites in the Ross drainage have particularly high sea-salt concentrations as a result of more efficient production of sea salts in the Ross Sea (elevated production rate of highly saline frost flowers) as compared to the Pine Island-Thwaites drainage system (Kaspari et al. 2005). For example, the mean $\mathrm{Na}^{+}$concentration from 1922 to 1991 at ITASE 01-3 (nearest PIG2010) was $18.4 \mathrm{ppb}$, compared with ITASE $00-4$ and $00-5$ in the Ross sector (nearest THW2010), which had mean $\mathrm{Na}^{+}$concentrations of 33.2 and 38.3 ppb, respectively (Kaspari et al. 2005). The wind anomalies along the western Amundsen Coast (offshore during winter and onshore during summer) during times of $\mathrm{Cl}^{-}$deposition at THW2010 (Figs. 10h,i) indicate that, similar to what we observe at PIG2010, sea salts from Ross Sea source regions are not transported to THW2010. The fact that the Ross Sea is not a moisture source region to THW2010 during times of $\mathrm{Cl}^{-}$deposition may account for the relatively low composite winter $\mathrm{Cl}^{-}$concentrations at THW2010 (Fig. 3). Finally, UPT2009 has the highest composite winter $\mathrm{Cl}^{-}$concentration (Fig. 3) and the strongest onshore winter wind anomalies of all four sites (Fig. 101). While UPT2009 is farthest inland, the site's relatively high elevation, and location within the Pine Island-Thwaites drainage system, exposes it to strong onshore wind anomalies in winter. Enhanced onshore winds along the Amundsen Coast and in particular from important sea ice formation regions farther afield near the leading ice edge and continental shelf in the Amundsen Sea directly increase the transport of sea salts from these source regions to UPT2009.

\section{c. SH teleconnection to the tropical Pacific}

Our regression analysis suggests that interannual variations in firn-core marine-aerosol records from the Amundsen Coast region of West Antarctica are linked with basin-scale SST variations particularly in the tropical Pacific that affect regional winds. Other studies have also identified a teleconnection between the tropical Pacific Ocean and aerosol deposition in Antarctica (Vance et al. 2013). Regressions of SST on PIG2010 winter $\mathrm{Cl}^{-}$anomalies (Fig. 4i), and THW2010 summer MSA and winter $\mathrm{Cl}^{-}$anomalies (Figs. 6g,i), are significant and negative in the eastern tropical Pacific. This SST pattern indicates La Niña-like conditions and, combined with the SLP and 500-hPa GH results, suggests that these sites may be more influenced by the tropical Pacific than the DIV2010 and UPT2009 sites. The distinct SAM-like pattern of SLP and 500-hPa GH seen with summer MSA at THW2010 suggests that the marine aerosols reaching this site are influenced by internal atmospheric dynamics, in addition to large-scale atmospheric dynamics. As discussed above, the proximity of DIV2010 to Pine Island Bay may result in a larger contribution of local dynamics (i.e., polynya variability) to the ice-sheet records (both marine biogenic and sea salt) at this most coastal site. The more inland location of UPT2009, as well as its relatively high elevation, may account for its lower overall summer MSA concentrations (as described above) and may also limit its sensitivity to regional dynamics driven by large-scale variability as compared to PIG2010 and THW2010. Similarly, the weaker regressions of global winter atmospheric fields on UPT2009 winter $\mathrm{Cl}^{-}$indicate that the high $\mathrm{Cl}^{-}$concentrations from offshore moisture source regions may not be sensitive to tropical Pacific dynamics. We also note that the well-studied, distinct changes between the 1980s and 1990s in the ENSO teleconnection to the high-latitude South Pacific (e.g., Fogt and Bromwich 2006) would be captured by the longer records in this study (DIV2010 and THW2010) but not the shorter records (PIG2010 and UPT2009), which may account for some of the observations discussed in this section.

The SIE results (Fig. 9), and to a lesser extent the TOWA results (Fig. 8), confirm the relationship between remote atmospheric dynamics that affect regional winds and Amundsen Sea sea ice variability, which impact ice-sheet marine-aerosol records. The regional SIE results also show the strong, well-established connection between Amundsen Sea sea ice variability and SAM (as has been previously shown, e.g., Lefebvre et al. 2004). The 500-hPa GH regression fields show similar results to the SLP regression fields in terms of the teleconnection to the Antarctic. While the associated SST regressions (Figs. 9e,f) in the eastern tropical Pacific are not as strong as the regressions of pressure fields (which show a clear Rossby wave train connecting the tropics to West Antarctica; Figs. 9a-d), there is relatively small amplitude of SST variability in the tropics when compared to the high latitudes, so the patterns we do see are both statistically and physically significant, and consistent with the other reanalysis results. As mentioned previously, tropical Pacific SST variability influences the upper troposphere, resulting in wave trains of alternating high and low pressure that emanate both north and south (Trenberth et al. 1998), as seen in our results. 
Our results highlight the importance of both seasonality and location on the impact of atmospheric teleconnections on marine aerosol variability. The impact of ENSO on SH atmospheric circulation is generally strongest in austral winter and spring (e.g., Jin and Kirtman 2010). The wave train pattern therefore becomes prominent in winter and spring, while a more annular pattern can be seen in summer. Our seasonal results reflect these changes in strength and development of the teleconnection. This is evident particularly at THW2010, where a SAM-like pattern is seen with summer regressions of SLP and 500-hPa GH on summer MSA, and a more organized wave train is seen with winter $\mathrm{Cl}^{-}$. Since sea-salt aerosols are deposited year-round, but largely in winter during sea ice formation, it is expected that $\mathrm{Cl}^{-}$ would be more strongly influenced by tropical forcing and atmospheric Rossby waves than biogenic aerosols, as we have shown at THW2010 and PIG2010. Further, comparison of the summer and winter regressions of SLP or 500-hPa GH on $\mathrm{Cl}^{-}$show that the wave train becomes more developed in winter, particularly at THW2010 (Fig. 6). Since marine biogenic aerosols originate from biological productivity during spring and summer, it is also expected that MSA may be more influenced by internal atmospheric variability than tropical forcing, since it is deposited when the teleconnection to the tropics is generally weakest. While the teleconnection may be weaker during times of MSA deposition, and there is certainly variability from site to site, our results do show that summer regressions of SLP, 500-hPa GH, and SST on summer MSA still reveal a significant link via a wave train to the tropical Pacific.

\section{Conclusions}

This work investigates the influence of tropical Pacific dynamics on marine aerosol transport to West Antarctica. We compare MSA and $\mathrm{Cl}^{-}$concentrations from four new West Antarctic firn cores with global reanalysis data of SLP, 500-hPa GH, SST, and surface wind velocity. The use of multiple core sites enables us to assess spatial variations in marine aerosol source and atmospheric transport as a function of distance from the coast as well as location within the catchments. Our key findings are that 1) the tropical Pacific influences both the overall source and transport of marine aerosols to the ice sheet through its remote control on regional winds; 2) weaker onshore winds (which can enhance katabatic flow and favor polynya formation along the Amundsen Coast) during times of MSA deposition suggest the polynyas are a major source region of MSA to the Amundsen sector of WAIS; 3) stronger onshore winds during times of sea-salt deposition at all but the most coastal core site suggest an offshore source region for sea salts to most of the Amundsen sector of WAIS, while local dynamics (i.e., polynya variability) may be more important nearer to the coast (i.e., at DIV2010); 4) regional sea ice behavior (SIE) is also strongly linked to the tropical Pacific via a Rossby wave train; and 5) MSA variability may be more influenced by internal atmospheric variability than $\mathrm{Cl}^{-}$variability (since MSA is deposited predominantly in summer when the teleconnection to the tropics is weakest), and $\mathrm{Cl}^{-}$variability may be more influenced by tropical forcing and atmospheric Rossby waves than biogenic aerosols (since $\mathrm{Cl}^{-}$is deposited largely in winter when the teleconnection to the tropics is strongest).

We show that both the source and transport of marine aerosols to West Antarctica are controlled by the dynamics of the response to remote atmospheric forcing. This study provides a first assessment of remote atmospheric forcing on Amundsen Coast marine-aerosol records, and benefits from the strength of having multiple coring sites that offer seasonal resolution. Our results should aid future interpretations of ice-core marineaerosol records in West Antarctica and provide additional evidence of the teleconnection between the tropical Pacific and West Antarctica (previously shown using SST, SLP, and SIC) with independent ice-sheet variables.

Acknowledgments. Thanks to Lou Albershardt, Howard Conway, Luke Trusel, Twila Moon, RPSC staff, and NICL staff for assistance in the field and with icecore processing. Thanks to DRI staff for continuous melter analyses. Thanks to Kevin Anchukaitis for assistance with the Monte Carlo simulations. We thank the two anonymous reviewers. This research was supported by an award from the Department of Energy Office of Science Graduate Fellowship Program (DOE SCGF) to ASC, a James E. and Barbara V. Moltz Research Fellowship to SBD, and grants from NSF-OPP (ANT0632031 and ANT-0631973), NSF-MRI (EAR1126217), and the NASA Cryosphere Program (NNX10AP09G), and a WHOI Andrew W. Mellon Foundation Award for Innovative Research.

\section{REFERENCES}

Abram, N. J., R. Mulvaney, E. W. Wolff, and M. Mudelsee, 2007: Ice core records as sea ice proxies: An evaluation from the Weddell Sea region of Antarctica. J. Geophys. Res., 112, D15101, doi:10.1029/2006JD008139.

,-- , and C. Arrowsmith, 2011: Environmental signals in a highly resolved ice core from James Ross Island, Antarctica. J. Geophys. Res., 116, D20116, doi:10.1029/2011JD016147.

_ E. W. Wolff, and M. A. J. Curran, 2013: A review of sea ice proxy information from polar ice cores. Quat. Sci. Rev., 79, 168-183. 
Arrigo, K. R., and G. L. van Dijken, 2003: Phytoplankton dynamics within 37 Antarctic coastal polynya systems. J. Geophys. Res., 108, 3271, doi:10.1029/2002JC001739.

— K. E. Lowry, and G. L. van Dijken, 2012: Annual changes in sea ice and phytoplankton in polynyas of the Amundsen Sea, Antarctica. Deep Sea Res. II, 71-76, 5-15.

Artaxo, P., M. L. C. Rabello, W. Maenhaut, and R. Van Grieken, 1992: Trace elements and individual particle analysis of atmospheric aerosols from the Antarctic Peninsula. Tellus, 44B, 318-334.

Ashok, K., S. K. Behera, S. A. Rao, H. Weng, and T. Yamagata, 2007: El Niño Modoki and its possible teleconnection. J. Geophys. Res., 112, C11007, doi:10.1029/2006JC003798.

Ayers, G. P., J. M. Cainey, R. W. Gillett, and J. P. Ivey, 1997: Atmospheric sulphur and cloud condensation nuclei in marine air in the Southern Hemisphere. Philos.Trans. Roy. Soc., 352B, 203-211.

Barber, D. G., and R. A. Massom, 2007: The role of sea ice in Arctic and Antarctic polynyas. Polynyas: Windows to the World, W. O. Smith and D. G. Barber, Eds., Elsevier, 1-54.

Berrisford, P., D. Dee, K. Fielding, M. Fuentes, P. Kallberg, S. Kobayashi, and S. Uppala, 2009: The ERA-Interim archive. ERA Report Series 1, ECMWF, 16 pp.

Bracegirdle, T. J., 2013: Climatology and recent increase of westerly winds over the Amundsen Sea derived from six reanalyses. Int. J. Climatol., 33, 843-851, doi:10.1002/joc.3473.

Bromwich, D. H., J. P. Nicolas, A. J. Monaghan, M. A. Lazzara, L. M. Keller, G. A. Weidner, and A. B. Wilson, 2013: Central West Antarctica among the most rapidly warming regions on Earth. Nat. Geosci., 6, 139-145.

Charlson, R. J., J. E. Lovelock, M. O. Andreae, and S. G. Warren, 1987: Oceanic phytoplankton, atmospheric sulphur, cloud albedo and climate. Nature, 326, 655-661.

Criscitiello, A. S., and Coauthors, 2013: Ice sheet record of recent sea-ice behavior and polynya variability in the Amundsen Sea, West Antarctica. J. Geophys. Res., 118, 118-130, doi:10.1029/ 2012JC008077.

Cullather, R. I., D. H. Bromwich, and M. L. Van Woert, 1996: Interannual variations in Antarctic precipitation related to El Niño-Southern Oscillation. J. Geophys. Res., 101 (D14), 19109-19118.

Cunningham, W. C., and W. H. Zoller, 1981: The chemical composition of remote area aerosols. J. Aerosol Sci., 12, 367-384.

Curran, M. A. J., and A. S. Palmer, 2001: Suppressed ion chromatography methods for the routine determination of ultra low level anions and cations in ice cores. J. Chromatogr., 919A, 107-113.

Dacey, J. W. H., and S. G. Wakeham, 1986: Oceanic dimethylsulfide: Production during zooplankton grazing on phytoplankton. Science, 233, 1314-1316.

Dee, D. P., and Coauthors, 2011: The ERA-Interim reanalysis: Configuration and performance of the data assimilation system. Quart. J. Roy. Meteor. Soc., 137, 553-597.

Ding, Q., E. J. Steig, D. S. Battisti, and M. Küttel, 2011: Winter warming in West Antarctica caused by central tropical Pacific warming. Nat. Geosci., 4, 398-403.

,,,--- and J. M. Wallace, 2012: Influence of the tropics on the southern annular mode. J. Climate, 25, 6330-6348.

Fischer, H., and Coauthors, 2007: Reconstruction of millennial changes in dust emission, transport and regional sea ice coverage using the deep EPICA ice cores from the Atlantic and Indian Ocean sector of Antarctica. Earth Planet. Sci. Lett., 260, $340-354$.
Fitzgerald, J. W., 1991: Marine aerosols: A review. Atmos. Environ., 25A, 533-545.

Fogt, R. L., and D. H. Bromwich, 2006: Decadal variability of the ENSO teleconnection to the high-latitude South Pacific governed by coupling with the southern annular mode. J. Climate, 19, 979-997.

,-- , and K. M. Hines, 2011: Understanding the SAM influence on the South Pacific ENSO teleconnection. Climate Dyn., 36, 1555-1576.

Fusco, G., G. Budillon, and G. Spezie, 2009: Surface heat fluxes and thermohaline variability in the Ross Sea and in Terra Nova Bay polynya. Cont. Shelf Res., 29, 1887-1895.

Gill, A. E., 1980: Some simple solutions for heat-induced tropical circulation. Quart. J. Roy. Meteor. Soc., 106, 447-462.

Hall, A., and M. Visbeck, 2002: Synchronous variability in the Southern Hemisphere atmosphere, sea ice, and ocean resulting from the annular mode. J. Climate, 15, 3043-3057.

Herron, M. M., 1982: Impurity sources of $\mathrm{F}^{-}, \mathrm{Cl}^{-}, \mathrm{NO}_{3}^{-}$and $\mathrm{SO}_{4}^{2-}$ in Greenland and Antarctic precipitation. J. Geophys. Res., 87 (C4), 3052-3060

Hezel, P. J., B. Alexander, C. M. Bitz, E. J. Steig, C. D. Holmes, X. Yang, and J. Sciare, 2011: Modeled methanesulfonic acid (MSA) deposition in Antarctica and its relationship to sea ice. J. Geophys. Res., 116, D23214, doi:10.1029/2011JD016383.

Hoskins, B. J., and D. J. Karoly, 1981: The steady linear response of a spherical atmosphere to thermal and orographic forcing. J. Atmos. Sci., 38, 1179-1196.

Jacobs, S., A. Jenkins, C. F. Giulivi, and P. Dutrieux, 2011: Stronger ocean circulation and increased melting under Pine Island Glacier ice shelf. Nat. Geosci., 4, 519-523.

Jenkins, A., P. Dutrieux, S. S. Jacobs, S. D. McPhail, J. R. Perrett, A. T. Webb, and D. White, 2010: Observations beneath Pine Island Glacier in West Antarctica and implications for its retreat. Nat. Geosci., 3, 468-472.

Jin, D., and B. P. Kirtman, 2010: The impact of ENSO periodicity on North Pacific SST variability. Climate Dyn., 34, 1015-1039.

Jin, F., and B. J. Hoskins, 1995: The direct response to tropical heating in a baroclinic atmosphere. J. Atmos. Sci., 52, 307-319.

Joughin, I., E. Rignot, C. E. Rosanova, B. K. Lucchitta, and J. Bohlander, 2003: Timing of recent accelerations of Pine Island Glacier, Antarctica. Geophys. Res. Lett., 30, 1706, doi:10.1029/2003GL017609.

Kaleschke, L., and Coauthors, 2004: Frost flowers on sea ice as a source of sea salt and their influence on tropospheric halogen chemistry. Geophys. Res. Lett., 31, L16114, doi:10.1029/ 2004GL020655.

Karoly, D. J., 1989: Southern Hemisphere circulation features associated with El Niño-Southern Oscillation events. J. Climate, 2, 1239-1252.

Kaspari, S., D. A. Dixon, S. B. Sneed, and M. J. Handley, 2005: Sources and transport pathways of marine aerosol species into West Antarctica. Ann. Glaciol., 41, 1-9.

Kinnard, C., C. M. Zdanowicz, D. A. Fisher, and C. P. Wake, 2006: Calibration of an ice-core glaciochemical (sea-salt) record with sea-ice variability in the Canadian Arctic. Ann. Glaciol., 44, 383-390.

Kreutz, K. J., and P. A. Mayewski, 1999: Spatial variability of Antarctic surface snow glaciochemistry: Implications for palaeoatmospheric circulation reconstructions. Antarct. Sci., 11, 105-118.

Kwok, R., and J. C. Comiso, 2002: Southern Ocean climate and sea ice anomalies associated with the Southern Oscillation. J. Climate, 15, 487-501. 
Lachlan-Cope, T., and W. Connolley, 2006: Teleconnections between the tropical Pacific and the Amundsen-Bellinghausens Sea: Role of the El Nino/Southern Oscillation. J. Geophys. Res., 111, D23101, doi:10.1029/2005JD006386.

Lee, S., T. Gong, N. Johnson, S. B. Feldstein, and D. Pollard, 2011: On the possible link between tropical convection and the Northern Hemisphere Arctic surface air temperature change between 1958 and 2001. J. Climate, 24, 4350-4367.

Lefebvre, W., H. Goosse, R. Timmermann, and T. Fichefet, 2004: Influence of the southern annular mode on the sea ice-ocean system. J. Geophys. Res., 109, C09005, doi:10.1029/2004JC002403.

Legrand, M., 1997: Ice-core records of atmospheric sulphur. Philos. Trans. Roy. Soc., 352B, 241-250.

L'Heureux, M. L., and D. W. J. Thompson, 2006: Observed relationships between the El Niño-Southern Oscillation and the extratropical zonal-mean circulation. J. Climate, 19, 276-287.

Liu, J., J. A. Curry, and D. G. Martinson, 2004: Interpretation of recent Antarctic sea ice variability. Geophys. Res. Lett., 31, L02205, doi:10.1029/2003GL018732.

Marshall, G. J., and J. Turner, 1997: Katabatic wind propagation over the western Ross Sea observed using ERS-1 scatterometer data. Antarct. Sci., 9, 221-226.

Maselli, O., D. Fritzche, L. Layman, J. McConnell, and H. Meyer, 2013: Comparison of water isotope ratio determinations using two cavity ring-down instruments and classical mass spectrometry in continuous ice-core analysis. Isot. Environ. Health Stud., 48, 387-398.

Massom, R. A., M. J. Pook, J. C. Comiso, N. Adams, J. Turner, T. Lachlan-Cope, and T. T. Gibson, 2004: Precipitation over the interior East Antarctic Ice Sheet related to midlatitude blocking-high activity. J. Climate, 17, 1914-1928.

Matsuno, T., 1966: Quasi-geostrophic motions in the equatorial area. J. Meteor. Soc. Japan, 44, 25-43.

McConnell, J. R., G. W. Lamorey, S. W. Lambert, and K. C. Taylor, 2001: Continuous ice-core chemical analyses using inductively coupled plasma mass spectrometry. Environ. Sci. Technol., 36, $7-11$.

Medley, B., and Coauthors, 2013: Airborne-radar and ice-core observations of annual snow accumulation over Thwaites Glacier, West Antarctica confirm the spatiotemporal variability of global and regional atmospheric models. Geophys. Res. Lett., 40, 3649-3654, doi:10.1002/grl.50706.

Meskhidze, N., and A. Nenes, 2006: Phytoplankton and cloudiness in the Southern Ocean. Science, 314, 1419-1423.

Miles, G. M., G. J. Marshall, J. R. McConnell, and A. J. Aristarain, 2008: Recent accumulation variability and change on the Antarctic Peninsula from the ERA40 reanalysis. Int. J. Climatol., 28, 1409-1422.

Morganti, A., S. Becagli, E. Castellano, M. Severi, R. Traversi, and R. Udisti, 2007: An improved flow analysis-ion chromatography method for determination of cationic and anionic species at trace levels in Antarctic ice cores. Anal. Chim. Acta, 603, 190-198.

Nylen, T. H., A. G. Fountain, and P. T. Doran, 2004: Climatology of katabatic winds in the McMurdo dry valleys, southern Victoria Land, Antarctica. J. Geophys. Res., 109, D03114, doi:10.1029/ 2003JD003937.

Okumura, Y. M., D. Schneider, C. Deser, and R. Wilson, 2012: Decadal-interdecadal climate variability over Antarctica and linkages to the tropics: Analysis of ice core, instrumental, and tropical proxy data. J. Climate, 25, 7421-7441.

Orsi, A. J., B. D. Cornuelle, and J. P. Severinghaus, 2012: Little Ice Age cold interval in West Antarctica: Evidence from borehole temperature at the West Antarctic Ice Sheet (WAIS) Divide. Geophys. Res. Lett., 39, L09710, doi:10.1029/2012GL051260.

Parish, T. R., and D. H. Bromwich, 1987: The surface windfield over the Antarctic ice sheets. Nature, 328, 51-54.

Pasteur, E. C., R. Mulvaney, D. A. Peel, E. S. Saltzman, and P.-Y. Whung, 1995: A 340 year record of biogenic sulphur from the Weddell Sea area, Antarctica. Ann. Glaciol., 21, 169-174.

Pease, C. H., 1987: The size of wind-driven coastal polynyas. J. Geophys. Res., 92 (C7), 7049-7059.

Petit, J. R., and Coauthors, 1999: Climate and atmospheric history of the past 420,000 years from the Vostok ice core, Antarctica. Nature, 399, 429-436.

Pszenny, A. A. P., A. J. Castelle, J. N. Galloway, and R. A. Duce, 1989: A study of the sulfur cycle in the Antarctic marine boundary layer. J. Geophys. Res., 94 (D7), 9818-9830.

Rankin, A. M., E. W. Wolff, and S. Martin, 2002: Frost flowers: Implications for tropospheric chemistry and ice core interpretation. J. Geophys. Res., 107, 4683, doi:10.1029/ 2002JD002492.

Ravishankara, A. R., Y. Rudich, R. Talukdar, and S. B. Barone, 1997: Oxidation of atmospheric reduced sulphur compounds: Perspective from laboratory studies. Philos. Trans. Roy. Soc., 352B, 171-182.

Rhodes, R. H., N. A. N. Bertler, J. A. Baker, S. B. Sneed, H. Oerter, and K. R. Arrigo, 2009: Sea ice variability and primary productivity in the Ross Sea, Antarctica, from methylsulphonate snow record. Geophys. Res. Lett., 36, L10704, doi:10.1029/ 2009GL037311.

Rignot, E., D. G. Vaughan, M. Schmeltz, T. Dupont, and D. MacAyeal, 2002: Acceleration of Pine Island and Thwaites Glaciers, West Antarctica. Ann. Glaciol., 34, 189-194.

Roscoe, H. K., B. Brooks, A. V. Jackson, M. H. Smith, S. J. Walker, R. W. Obbard, and E. W. Wolff, 2011: Frost flowers in the laboratory: Growth, characteristics, aerosol, and the underlying sea ice. J. Geophys. Res., 116, D12301, doi:10.1029/ 2010JD015144.

Schneider, D. P., and E. J. Steig, 2008: Ice cores record significant 1940s Antarctic warmth related to tropical climate variability. Proc. Natl. Acad. Sci. USA, 105, 12154-12158.

- C. Deser, and Y. Okumura, 2012: An assessment and interpretation of the observed warming of West Antarctica in the austral spring. Climate Dyn., 38, 323-347.

Shepherd, A., D. J. Wingham, and J. A. D. Mansley, 2002: Inland thinning of the Amundsen Sea sector, West Antarctica. Geophys. Res. Lett., 29, 1364, doi:10.1029/2001GL014183.

Simpkins, G. R., L. M. Ciasto, D. W. J. Thompson, and M. H. England, 2012: Seasonal relationships between large-scale climate variability and Antarctic sea ice concentration. J. Climate, 25, 5451-5469.

Smith, W. O., Jr., and L. I. Gordon, 1997: Hyperproductivity of the Ross Sea (Antarctica) polynya during austral spring. Geophys. Res. Lett., 24, 233-236.

_ J. Marra, M. R. Hiscock, and R. T. Barber, 2000: The seasonal cycle of phytoplankton biomass and primary productivity in the Ross Sea, Antarctica. Deep-Sea Res. II, 47, 3119-3140.

Stammerjohn, S. E., D. G. Martinson, R. C. Smith, X. Yuan, and D. Rind, 2008: Trends in Antarctic annual sea ice retreat and advance and their relation to El Niño-Southern Oscillation and southern annular mode variability. J. Geophys. Res., 113, C03S90, doi:10.1029/2007JC004269. 
Steig, E. J., and Coauthors, 2013: Recent climate and ice-sheet changes in West Antarctica compared with the past 2,000 years. Nat. Geosci., 6, 372-375.

—, D. P. Schneider, S. D. Rutherford, M. E. Mann, J. C. Comiso, and D. T. Shindell, 2009: Warming of the Antarctic ice-sheet surface since the 1957 International Geophysical Year. $\mathrm{Na}$ ture, 457, 459-462.

—, Q. Ding, D. S. Battisti, and A. Jenkins, 2012: Tropical forcing of circumpolar deep water inflow and outlet glacier thinning in the Amundsen Sea embayment, West Antarctica. Ann. Glaciol., 53, 19-28.

Thomas, E. R., P. F. Dennis, T. J. Bracegirdle, and C. Franzke, 2009: Ice core evidence for significant 100-year regional warming on the Antarctic Peninsula. Geophys. Res. Lett., 36, L20704, doi:10.1029/2009GL040104.

Trenberth, K. E., G. W. Branstator, D. Karoly, A. Kumar, N.-C. Lau, and C. Ropelewski, 1998: Progress during TOGA in understanding and modeling global teleconnections associated with tropical sea surface temperatures. J. Geophys. Res., 103 (C7), 14291-14324.

Trusel, L. D., K. E. Frey, and S. B. Das, 2012: Antarctic surface melting dynamics: Enhanced perspectives from radar scatterometer data. J. Geophys. Res., 117, F02023, doi:10.1029/ 2011JF002126.

Turner, J., 2004: The El Niño-Southern Oscillation and Antarctica. Int. J. Climatol., 24, 1-31.
Vance, T. R., T. D. van Ommen, M. A. J. Curran, C. T. Plummer, and A. D. Moy, 2013: A millennial proxy record of ENSO and eastern Australian rainfall from the Law Dome ice core, East Antarctica. J. Climate, 26, 710-725.

Weller, R., F. Traufetter, H. Fischer, H. Oerter, C. Piel, and H. Miller, 2004: Postdepositional losses of methanesulfonate, nitrate, and chloride at the European Project for Ice Coring in Antarctica deep-drilling site in Dronning Maud Land, Antarctica. J. Geophys. Res., 109, D07301, doi:10.1029/ 2003JD004189.

Wolff, E. W., A. M. Rankin, and R. Röthlisberger, 2003: An ice core indicator of Antarctic sea ice production? Geophys. Res. Lett., 30, 2158, doi:10.1029/2003GL018454.

- and Coauthors, 2006: Southern Ocean sea-ice extent, productivity and iron flux over the past eight glacial cycles. $\mathrm{Na}$ ture, 440, 491-496.

Yang, X., J. A. Pyle, and R. A. Cox, 2008: Sea salt aerosol production and bromine release: Role of snow on sea ice. Geophys. Res. Lett., 35, L16815, doi:10.1029/2008GL034536.

Yuan, X., and C. Li, 2008: Climate modes in southern high latitudes and their impacts on Antarctic sea ice. J. Geophys. Res., 113, C06S91, doi:10.1029/2006JC004067.

—, and D. G. Martinson, 2001: The Antarctic dipole and its predictability. Geophys. Res. Lett., 28, 3609-3612.

Zhang, Y., J. M. Wallace, and D. S. Battisti, 1997: ENSOlike interdecadal variability: 1900-93. J. Climate, 10, 10041020. 